\title{
Monitoringsprotocol Energie Duurzame Zuivelketen
}

M.W. Hoogeveen, R.J.K. Helmes, G.J. Doornewaard, P.X. Smit en J.W. Reijs

LE I

WAGENINGEN UR 


\section{Monitoringsprotocol Energie Duurzame Zuivelketen}

M.W. Hoogeveen, R.J.K. Helmes, G.J. Doornewaard, P.X. Smit en J.W. Reijs

Dit onderzoek is uitgevoerd door LEI Wageningen UR in opdracht van de Duurzame Zuivelketen en gefinancierd door het Zuivel NL en het ministerie van Economische Zaken, in het kader van de PPS Duurzame Zuivelketen, onderdeel van topsector Agri\&Food.

LEI Wageningen UR

Wageningen, juni 2016

RAPPORT

LEI 2016-043

ISBN 978-94-6257-816-6

LE I 
Hoogeveen, M.W., R.J.K. Helmes, G.J. Doornewaard, P.X. Smit en J.W. Reijs, 2016.

Monitoringsprotocol Energie Duurzame Zuivelketen. Wageningen, LEI Wageningen UR (University \&

Research centre), LEI Rapport 2016-043. 46 blz.; 6 fig.; 4 tab.; 18 ref.

Via het initiatief de Duurzame Zuivelketen streven zuivelondernemingen en melkveehouders gezamenlijk naar een toekomstbestendige en verantwoorde zuivelsector. Voor het thema 'Klimaatneutraal ontwikkelen' is een monitoringsprotocol ontwikkeld. Dit protocol beschrijft op systematische wijze de te hanteren rekenmethodes en databronnen. Het protocol is op verzoek van de stuurgroep Duurzame Zuivelketen opgesteld en door LEI Wageningen UR in samenwerking met het programmateam 'Klimaatneutraal ontwikkelen' en diverse stakeholders ontwikkeld. Ook is dit project benut om verbeteringen in de monitor door te voeren, zodat de sectorontwikkelingen op de energiedoelstellingen beter inzichtelijk zijn.

With the Sustainable Dairy Chain initiative, dairy businesses and dairy farmers are pursuing a futureproof and responsible dairy sector. A monitoring protocol has been developed for the theme 'Climateneutral development'. This protocol describes the calculation methods and data sources in a systematic manner. The protocol was created following a request by the Sustainable Dairy Chain steering group and developed by LEI Wageningen UR in collaboration with the 'Climate-neutral development' programme team and various other stakeholders. This project was also used to make improvements to the monitor thus providing more insight into sector developments in terms of the energy objectives.

Trefwoorden: Duurzame Zuivelketen, Energie, Protocol, Monitoring, Duurzame Energie, Energieefficiëntie, $\mathrm{CO}_{2}$-emissie, Melkveehouderij

Dit rapport is gratis te downloaden op http://dx.doi.org/10.18174/381213 of op www. wageningenUR. nl/lei (onder LEl publicaties).

(C) 2016 LEI Wageningen UR

Postbus 29703, 2502 LS Den Haag, T 07033583 30, E informatie.lei@wur.nl,

www. wageningenUR.nl/lei. LEI is onderdeel van Wageningen UR (University \& Research centre).

\section{(cc) BY-NC}

LEI hanteert voor haar rapporten een Creative Commons Naamsvermelding 3.0 Nederland licentie.

(c) LEI, onderdeel van Stichting Dienst Landbouwkundig Onderzoek, 2016

De gebruiker mag het werk kopiëren, verspreiden en doorgeven en afgeleide werken maken. Materiaal van derden waarvan in het werk gebruik is gemaakt en waarop intellectuele eigendomsrechten berusten, mogen niet zonder voorafgaande toestemming van derden gebruikt worden. De gebruiker dient bij het werk de door de maker of de licentiegever aangegeven naam te vermelden, maar niet zodanig dat de indruk gewekt wordt dat zij daarmee instemmen met het werk van de gebruiker of het gebruik van het werk. De gebruiker mag het werk niet voor commerciële doeleinden gebruiken.

Het LEI aanvaardt geen aansprakelijkheid voor eventuele schade voortvloeiend uit het gebruik van de resultaten van dit onderzoek of de toepassing van de adviezen.

Het LEI is ISO 9001:2008 gecertificeerd.

LEI 2016-043 | Projectcode 2282200113

Foto omslag: Shutterstock 


\section{Inhoud}

Woord vooraf $\quad 5$

$\begin{array}{ll}\text { Samenvatting } & 6\end{array}$

S.1 Aanleiding 6

S.2 Verbeteringen $\quad 6$

$\begin{array}{ll}\text { S.3 Aanbevelingen } & 7\end{array}$

$\begin{array}{lll}\text { S.4 Methode } & 7\end{array}$

$\begin{array}{ll}\text { Summary } & 8\end{array}$

$\begin{array}{lll}\text { S.1 Background } & 8\end{array}$

S.2 Improvements $\quad 8$

S.3 Recommendations $\quad 9$

S.4 Method 9

$\begin{array}{llr}1 & \text { Inleiding } & 10\end{array}$

1.1 De Duurzame Zuivelketen $\quad 10$

1.2 Aanleiding en doel van dit protocol $\quad 10$

$\begin{array}{lll}1.3 & \text { Opbouw protocol } & 11\end{array}$

$\begin{array}{ll}1.3 .1 \text { Inhoud } & 11\end{array}$

1.3.2 Proces van opstellen 11

$\begin{array}{llr}2 & \text { Veel gebruikte termen } & 13\end{array}$

$3 \quad$ Indicatoren en berekeningswijze $\quad 14$

3.1 Doelen en indicatoren Duurzame Zuivelketen $\quad 14$

$\begin{array}{ll}3.2 & \text { Beschrijving energiestromen } \\ \end{array}$

$\begin{array}{lll}3.3 & \text { Afbakening } & 16\end{array}$

$\begin{array}{lll}3.4 & \text { Subthema energie- efficiëntie } & 17\end{array}$

3.4.1 Doel en achtergrond 17

3.4.2 Indicatoren 18

$\begin{array}{ll}\text { 3.4.3 Methode } & 18\end{array}$

3.5 Subthema duurzame energieproductie $\quad 20$

3.5.1 Doel en achtergrond $\quad 20$

$\begin{array}{ll}3.5 .2 \text { Indicatoren } & 20\end{array}$

$\begin{array}{ll}3.5 .3 \text { Methode } & 21\end{array}$

$\begin{array}{lll}3.6 & \text { Subthema broeikasgasemissie } & 21\end{array}$

3.6.1 Doel en achtergrond $\quad 21$

3.6.2 Indicatoren $\quad 21$

$\begin{array}{ll}3.6 .3 \text { Methode } & 22\end{array}$

$4 \quad$ Databronnen en -gebruik $r 2$

4.1 Inleiding 23

4.2 Databronnen 23

$\begin{array}{lll}4.3 & \text { Datagebruik Melkveebedrijven } & 26\end{array}$

4.3.1 Energie-inkoop en -gebruik melkveebedrijven 26

4.3.2 Energieproductie en -verkoop melkveebedrijven $\quad 27$

$\begin{array}{lll}4.4 & \text { Datagebruik Logistiek } & 28\end{array}$

$\begin{array}{lll}4.5 & \text { Datagebruik Zuivelverwerkers } & 29\end{array}$

$\begin{array}{lll}4.6 & \text { Omrekeningsfactoren } & 29\end{array}$

4.6.1 Primaire brandstoffactoren $\quad 29$

4.6.2 Emissiefactoren 30 


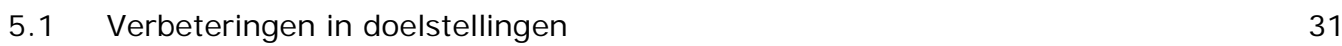

5.2 Energiestromen bij de melkveebedrijven $\quad 31$

5.3 Energiestromen bij het melktransport 33

5.4 Energiestromen bij de melkverwerkers 33

5.5 Uitgevoerde en toekomstige verbeteringen 33

$\begin{array}{ll}\text { Literatuur en websites } & 35\end{array}$

$\begin{array}{lll}\text { Bijlage } 1 & \text { Leden van stakeholdergroepen } & \mathbf{3 7}\end{array}$

$\begin{array}{lll}\text { Bijlage } 2 & \text { Overzicht Energiestromen } & 38\end{array}$

Bijlage $3 \quad$ Overzichtstabel indicatoren en rekenmethoden 39

Bijlage 4 Opzet pilot met zuivelverwerkers 41

Bijlage 5 Monitoring doelstelling '20\% reductie ten opzichte van 1990' 42

$\begin{array}{lll}\text { Bijlage } 6 & \text { Samenvatting broeikasgasberekeningen } & 43\end{array}$ 


\section{Woord vooraf}

De Duurzame Zuivelketen is een uniek initiatief waarin de zuivelindustrie en melkveehouders er gezamenlijk naar streven om de Nederlandse zuivelsector te verduurzamen. Vanwege de positie op de (internationale) markt en in de maatschappij is het voor de zuivelketen belangrijk om proactief in te spelen op uitdagingen op het gebied van duurzaamheid. De Nederlandse Zuivel Organisatie (NZO) en LTO Nederland hebben in de Duurzame Zuivelketen in 2011 gezamenlijke doelstellingen vastgesteld rond 4 thema's: 1) Klimaatneutraal ontwikkelen, 2) Continu verbeteren diergezondheid en dierenwelzijn, 3) Behoud weidegang en 4) Behoud biodiversiteit \& milieu. LEI Wageningen UR wil graag bijdragen aan het realiseren van deze verduurzaming door objectief te rapporteren en daarmee inzicht te bieden in de stand van zaken. De sectorrapportages doen sinds 2011 ieder jaar verslag van de prestaties van de Nederlandse zuivelsector op de doelen van de Duurzame Zuivelketen (zie onder andere Reijs et al., 2015).

De aanleiding voor de ontwikkeling van dit protocol was de conclusie in de sectorrapportage over 2012 (Reijs et al., 2013b) dat de ontwikkelingen in de doelstellingen voor 'Klimaatneutraal ontwikkelen' beter in beeld moesten worden gebracht. De resultaten van de genomen initiatieven op het thema 'Klimaatneutraal ontwikkelen' konden namelijk niet voldoende met de indicatoren worden gemonitord. Er zijn meer gegevens uit nieuwe bronnen nodig, evenals verbetering van de monitoring, om de ontwikkelingen in beeld te brengen, en dit protocol beschrijft de benodigde databronnen en rekenmethodes. Daarmee maakt dit protocol de rapportage van de energiedoelstellingen inzichtelijk op een wetenschappelijk onderbouwde en in de praktijk geaccepteerde manier.

Dit protocol is met hulp van veel mensen tot stand gekomen. De auteurs bedanken allereerst de mensen die hen van feedback op de rekenmethodiek en informatie over andere monitors hebben voorzien. De klankbordgroep, die ten behoeve van dit project is opgesteld, heeft daarin een grote rol gespeeld. Daarnaast willen zij het programmateam 'Klimaatneutraal ontwikkelen' en alle LEI-collega's bedanken die aan dit protocol hebben bijgedragen. Tot slot een woord van dank aan de stuurgroep van Duurzame Zuivelketen voor de inspirerende begeleiding bij het uitvoeren van dit onderzoek en het opstellen van dit protocol. De leden van de hierboven genoemde groepen staan vermeld in Bijlage 1.

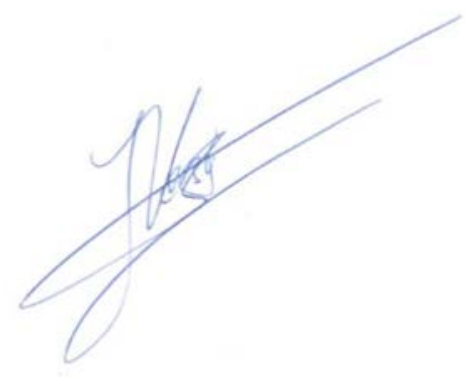

Prof. dr. ir. Jack (J.G.A.J.) van der Vorst

Algemeen Directeur SSG Wageningen UR 


\section{Samenvatting}

\section{S.1 Aanleiding}

In de eerdere sectorrapportages van de Duurzame Zuivelketen werd geconcludeerd dat er meer gegevens uit nieuwe bronnen en verbeteringen van de monitoring nodig zijn om de ontwikkelingen in de doelstellingen voor 'Klimaatneutraal ontwikkelen' goed in beeld te brengen. In reactie hierop is LEI Wageningen UR door de Duurzame Zuivelketen gevraagd een protocol te ontwikkelen.

Dit Monitoringsprotocol Energie Duurzame Zuivelketen zorgt ervoor dat de verschillende indicatoren op het subthema 'Klimaatneutraal ontwikkelen' ieder jaar systematisch kunnen worden geëvalueerd, door de rekenmethodes vast te stellen en de geschikte databronnen voor te schrijven. Dit leidt tot meer transparantie en een betere kwaliteit.

Het protocol is al toegepast in de Sectorrapportage over 2014, die in december 2015 is verschenen en zal ook worden toegepast in toekomstige sectorrapportages. De belangrijkste verbeteringen voor de drie subthema's staan hieronder beschreven.

\section{S.2 Verbeteringen}

De indicator voor het thema energie-efficiëntie, primair brandstofverbruik van de zuivelketen (uitgedrukt in primair brandstofverbruik in $\mathrm{m}^{3}$ aardgasequivalenten per $1.000 \mathrm{~kg}$ melk per jaar) is verbeterd doordat gebruik is gemaakt van gegevens van zowel duurzame als conventionele energieconsumptie van de melkveebedrijven in het Bedrijveninformatienet van het LEI en van het bijmengingspercentage van biodiesel in de dieselconsumptie. De dieselconsumptie door loonwerk is gebaseerd op praktijkgegevens van de brandstofkosten in relatie tot het loonwerktarief, specifiek voor loonwerk op melkveebedrijven (CUMELA).

De hoofdindicator voor het thema duurzame energie, productie van duurzame energie in het betreffende jaar ten opzichte van de geconsumeerde energie in de zuivelketen, is een verhoudingsgetal tussen de hoeveelheid geproduceerde duurzame energie en de hoeveelheid geconsumeerde energie in de zuivelketen (\%). Deze indicator is nieuw ten opzichte van eerdere rapportages en maakt gebruik van gegevens van de zonne-energieproductie op melkveebedrijven (Bedrijveninformatienet) en actuele gegevens over de energieproductie van windmolens en biogasinstallaties (CBS).

De beschreven systematiek wordt ook gebruikt voor het berekenen van de hoofdindicator op het thema broeikasgassen, broeikasgasemissie van de zuivelketen, uitgedrukt de broeikasgasemissie van de zuivelketen (Mton $\mathrm{CO}_{2}$-eq). Deze indicator is verbeterd doordat gebruik is gemaakt van verbeterde gegevens in het Informatienet over energieconsumptie, bijmenging van biodiesel en de brandstofconsumptie van loonwerk.

Het opstellen van het protocol heeft geleid tot een herziening van de afbakening van de zuivelketen en wijziging in de te hanteren indicatoren. De zuivelketen omvat drie schakels; de melkveebedrijven, logistieke bedrijven en zuivelverwerkers. Voor de energie-indicatoren is de keten afgebakend tot de energieconsumptie behorend tot de activiteiten op bedrijven in deze drie schakels van de zuivelketen. Energieconsumptie van de toeleveringsketen (bijvoorbeeld kunstmest- en mengvoederproductie) werd beschouwd als buiten de keten, en wordt met ingang van de rapportage over 2015 in de energieindicatoren opgenomen. De broeikasgasemissies van de toeleveringsketen waren dankzij de 'cradle to factory gate'-benadering al betrokken in de bepaling van de emissie in de voorgaande jaren. 


\section{S.3 Aanbevelingen}

In lijn met het ontwikkelde protocol zijn er wel een aantal aanbevelingen om de monitoring van het thema 'Klimaatneutraal ontwikkelen' in de komende jaren verder te verbeteren. De belangrijkste aanbevelingen zijn het jaarlijks uitzetten van een vragenformulier gericht aan de zuivelondernemingen, dat in dit project is ontwikkeld, en beter af te spreken welke wind- en zonneenergieproductie aan de zuivelsector kan worden toegerekend, waarbij dit met de juiste databronnen mogelijk wordt gemaakt.

\section{S.4 Methode}

Dit protocol beschrijft op systematische wijze de te hanteren rekenmethodes en databronnen. Dit protocol bevat ook de verantwoording van het project 'Verbeteren Energiemonitoring Duurzame Zuivelketen'. In dit project zijn eerst de uitgangspunten voor de definities van de indicatoren, de afbakening van de keten, de toe te passen rekenregels en -methodieken en de specificatie van de data opgesteld en voorgelegd aan het programmateam 'Klimaatneutraal ontwikkelen' van de Duurzame Zuivelketen en een klankbordgroep van stakeholders. Vervolgens zijn de relevante databronnen geïnventariseerd en beoordeeld op de mogelijke bijdrage aan de werkwijze. In een pilot met twee zuivelondernemingen is een vragenformulier opgesteld voor inventarisatie van gegevens van de drie ketenschakels bij de zuivelondernemingen. Deze vragenlijst is getest door twee zuivelondernemingen en geëvalueerd. Na deze stappen is het protocol opgesteld en gepresenteerd aan het programmateam en de klankbordgroep. Ten slotte zijn opmerkingen en feedback van programmateam en klankbordgroep verwerkt bij het opstellen van deze eindrapportage. 


\section{Summary}

\section{S.1 Background}

In previous sector reports by the Sustainable Dairy Chain, it was ascertained that more information from new sources and improvements in monitoring would be necessary to clarify the development of the objectives set for 'Climate-neutral development'. The Sustainable Dairy Chain consequently requested LEI Wageningen UR to develop a protocol.

This Energy Sustainable Dairy Chain monitoring protocol ensures that the different indicators for the 'Climate-neutral development' sub-theme can be evaluated systematically every year by establishing the calculation methods and recommending relevant data sources. This results in more transparency and improved quality.

This protocol has already been applied to the 2014 sector report that was published in December 2015 and will also be applied to future sector reports. The most significant improvements for the three subthemes are described below.

\section{S.2 Improvements}

The indicator for the theme energy efficiency, primary fuel consumption of the dairy chain (expressed as primary fuel consumption in $\mathrm{m}^{3}$ of natural gas per $1,000 \mathrm{~kg}$ of milk per year) has been improved by using the sustainable as well as conventional energy consumption data of dairy farms registered in the LEI Wageningen UR Farm Accountancy Data Network (FADN) and the blending percentage of biodiesel in diesel consumption. The diesel consumption resulting from contract work is based on practical data about fuel costs in relation to the contract work rates, specifically for contract work at dairy farms (CUMELA).

The main indicator for the theme sustainable energy, production of sustainable energy in the relevant year compared to the energy used by the dairy chain, is a ratio between the amount of sustainable energy that is produced and the amount of energy used in the dairy chain (\%). This indicator is a new addition to the previous reports and uses data from the solar energy production of dairy farms (FADN) and up-to-date data about the energy production of windmills and biogas installations (Statistics Netherlands, CBS).

The system described is also used for calculating the main indicator for the theme 'greenhouse gasses, ' greenhouse gas emissions of the dairy chain, expressed as greenhouse gas emissions of the dairy chain (Mtonnes $\mathrm{CO}_{2}$-Eq). This indicator has been improved by using revised data from the FADN about energy consumption, blending of biodiesel and the fuel consumption as a result of contract work.

The creation of the protocol has resulted in a revision of the definition of the dairy chain and changes in the indicators to be used. The dairy chain contains three links: the dairy farms, logistics companies and dairy processors. For the energy indicators, the chain has been limited to the energy consumption of the activities of the companies in the three links of the dairy chain. The energy consumption of the supply chain, including artificial fertilisers and compound feed production, has been considered as being outside of the chain and this decision will be applied to the energy indicators of the 2015 report. Greenhouse gas emissions of the supply chain were already included in the emission calculations of previous years as a result of the 'cradle to factory gate' approach. 


\section{S.3 Recommendations}

Following the protocol that has been developed, there are several recommendations to improve the monitoring of the theme 'Climate-neutral development' in the next few years. The most important recommendations are sending out the questionnaire that has been developed for this project to dairy businesses every year, and to make clearer agreements about which wind and solar energy production can be attributed to the dairy chain and that this is supported with correct data sources.

\section{S.4 Method}

This protocol describes the calculation methods and data sources in a systematic manner. This protocol also contains the motivation for the project 'I mproving the monitoring of energy in the Sustainable Dairy Chain'. First, this project defined the starting points for the definitions of the indicators, the definition of the chain, the applicable calculation rules and methodologies and the specification of data, and then submitted these to the 'Climate-neutral development' programme team' of the Sustainable Dairy Chain and a focus group of stakeholders. The relevant data sources were then inventoried and assessed according to their applicability to the working method. During a pilot with two dairy companies, a questionnaire was put together for the inventory of data about the three links in the chain at these dairy companies. This questionnaire was tested by two dairy companies and evaluated. After these steps, the protocol was created and presented to the programme team and the focus group. Finally, the comments and feedback provided by the programme team and focus group were processed for the writing of this final report. 


\section{$1 \quad$ Inleiding}

\section{$1.1 \quad$ De Duurzame Zuivelketen}

De Nederlandse Zuivel Organisatie (NZO) en de vakgroep melkveehouderij LTO Nederland hebben hun krachten gebundeld in de Duurzame Zuivelketen. Via de Duurzame Zuivelketen zetten zuivelindustrie en melkveehouders zich gezamenlijk in voor het versterken van het toekomstig draagvlak in markt en maatschappij. De Duurzame Zuivelketen heeft doelen geformuleerd rond vier thema's:

1. 'Klimaatneutraal ontwikkelen'

2. Continu verbeteren dierenwelzijn

3. Behoud weidegang en

4. Behoud biodiversiteit \& milieu.

In opdracht van de stuurgroep Duurzame Zuivelketen stelt LEI Wageningen UR een jaarlijkse sectorrapportage op die inzicht geeft in de voortgang in het realiseren van de vastgestelde doelen (Reijs et al., 2013a, Reijs et al., 2013b en Reijs et al., 2014).

\subsection{Aanleiding en doel van dit protocol}

In de sectorrapportage over 2012 (Reijs et al., 2013b) werd geconstateerd dat op een aantal vlakken verdere concretisering en aanscherping van doelen en monitoring nodig is om vooruitgang op de geformuleerde doelen meetbaar te maken. In september 2014 zijn de doelstellingen van de Duurzame Zuivelketen herijkt om gewijzigd beleid en verkregen inzichten in de sectorrapportage te verwerken en om de doelen beter meetbaar te maken. Deze herijking wordt beschreven in de sectorrapportage over 2013 (Reijs et al., 2014). Om de drie doelen van het thema 'Klimaatneutraal ontwikkelen' beter te kunnen monitoren, dienen er meer en betere gegevens beschikbaar te worden gemaakt en de indicatoren en hun berekeningswijze beter te worden geformuleerd. Vooral de effecten van duurzame energieproductie en -consumptie dienen beter in beeld te worden gebracht.

\section{Doelen 'Klimaatneutraal ontwikkelen' van de Duurzame Zuivelketen}

1. Klimaatneutrale groei ten opzichte van 2011 en $20 \%$ reductie van broeikasgassen door de zuivelketen ten opzichte van 1990 in 2020

2. Zestien procent productie van duurzame energie in 2020 in de zuivelketen

3. Verbeteren energie-efficiëntie van de zuivelketen van gemiddeld $2 \%$ per jaar in $2005-2020$ Kadertekst

De stuurgroep van de Duurzame Zuivelketen heeft verzocht om de monitoring in de sectorrapportage op het thema 'Klimaatneutraal ontwikkelen' te verbeteren. Het voorliggende protocol is het resultaat en beschrijft de methodiek voor het meerjarig monitoren van de drie doelen, op wetenschappelijk verantwoorde en goed gedocumenteerde wijze. Deze verbeteringen in de monitoring werden voor het eerst toegepast in de sectorrapportage over 2014, die in het najaar van 2015 werd gepubliceerd. Uiteindelijk zal de verbeterde monitoring de Duurzame Zuivelketen helpen bij het evalueren en aanscherpen van het eigen programma. Ook geeft het de Duurzame Zuivelketen meer houvast in de communicatie met overheden, klanten en maatschappelijke organisaties over gerealiseerde prestaties op dit thema. 


\subsection{Opbouw protocol}

\subsubsection{Inhoud}

Dit protocol begint met de belangrijkste definities voor het protocol in hoofdstuk 2 . Het protocol werkt de afbakening van de keten, de opsplitsing naar energiesoorten en de toelichting op indicatoren consistent uit om de berekening van alle indicatoren op een eenduidige manier mogelijk te maken in de eerste helft van hoofdstuk 3. Deze berekeningen worden vervolgens consistent beschreven in dit protocol, waarbij de bijdrages van duurzame energie in iedere berekening worden meegenomen, in de tweede helft van hoofdstuk 3.

In hoofdstuk 4 wordt beschreven welke data benodigd zijn en welke bronnen deze data leveren voor de sectorreportage over 2014. De verschillende databronnen voor de productie en het gebruik van duurzame energie zijn eerst geëvalueerd. Waar nodig en mogelijk worden databronnen en methoden vernieuwd voor de berekening van alle indicatoren.

Er is met dit protocol een eenvoudige, minimale, versie van de berekeningsmethode uitgewerkt, die haalbaar is voor uitvoering van de rapportage over 2014, in het najaar van 2015. Verbeteringen die zeker in de volgende sectorrapportage (uitgevoerd in 2016, over 2015) worden doorgevoerd, staan ook in de hoofdstukken 3 en 4 beschreven. Dit protocol wordt ook voor de latere rapportages gevolgd. In de loop van de jaren 2016-2020 kunnen stappen worden gezet om van een simpele tot een gedetailleerdere en accuratere monitoring te komen. Deze verbeterpunten voor de langere termijn worden in hoofdstuk 5 beschreven, ter overweging door de betrokken partijen, waaronder het Programmateam 'Klimaatneutraal ontwikkelen'.

\subsubsection{Proces van opstellen}

In de dialoog met de stuurgroep van de Duurzame Zuivelketen, waarin de wens om de monitoring op het thema 'Klimaatneutraal ontwikkelen' te verbeteren werd vertaald naar een offerte en een opdracht, zijn enkele verbeteringen en uitgangspunten voorgesteld door de stuurgroep en het LEI. In het project dat volgde is het protocol in verschillende stappen opgesteld. Deze zijn hieronder beschreven:

1. De uitgangspunten voor het protocol zijn eerst afgestemd. Daartoe zijn de uitgangspunten door LEI Wageningen UR uitgewerkt: de definities van de indicatoren zijn gecontroleerd en waar nodig verder uitgewerkt en de afbakening en de rekenmethodiek is beschreven. Ook de datavraag en de eisen zijn vastgesteld. Op deze uitgangspunten is feedback verzameld van sectorstakeholders en deze is verwerkt. Vervolgens heeft het programmateam 'Klimaatneutraal ontwikkelen' deze goedgekeurd.

2. Op basis van de bovengenoemde uitgangspunten zijn de te hanteren rekenregels en normen samengevat. Er is een overzicht gemaakt van welke data benodigd zijn voor alle ketenschakels en op welke manier (vanuit welke bronnen) zij nu en in de toekomst te verzamelen zijn. Mogelijke databronnen zijn beoordeeld op betrouwbaarheid, continuïteit en kosten. Hierbij is onderscheid gemaakt naar de korte (2014/2015) en de lange termijn (tot 2020). Er is hierbij rekening gehouden dat uitvoering binnen het huidige budget van de sectorrapportage Duurzame Zuivelketen moet kunnen plaatsvinden. De beschikbare capaciteit is momenteel beperkt tot 5-10 dagen voor energiemonitoring. Ook gebruik van data van andere partijen is alleen mogelijk als dit niet leidt tot extra kosten. Verbeteropties die meer tijd of geld vergen, worden in eerste instantie niet in het protocol opgenomen. Indien deze verbeteropties wel effectief en kansrijk worden geacht, worden ze beschreven als toekomstige verbeteropties (hoofdstuk 5).

3. De klankbordgroep van sectorstakeholders is waar nodig vooraf gevraagd om input. Ook hebben de leden van de klankbordgroep in een bijeenkomst feedback gegeven op de conceptresultaten.

4. Er is een vragenlijst ontwikkeld waarmee energiedata die zuivelverwerkers zelf al vastleggen kan worden verzameld. De hoeveelheid data en de kwaliteit ervan zal nog verder toenemen in de loop der jaren. Deze spreadsheet is met twee van de deelnemende zuivelondernemingen getest in een pilot (zie bijlage 4 Opzet pilot met zuivelverwerkers). De conclusie van de pilot is dat de vragen in de vragenlijst duidelijk en logisch zijn is en de benodigde tijdsinspanning beperkt is met ongeveer een halfuur. Mogelijke verbeteringen hebben vooral betrekking op het proces van het uitzetten 
van de vragenlijst, waarbij de wens is om dit in twee in plaats van in één stap te doen. In een eerste stap dienen de voorwaarden voor het gebruik van de door zuivelverwerkers aan te leveren data te worden overeengekomen. Hierbij valt te denken aan voorwaarden als het niet publiceren van individuele gegevens van zuivelverwerkers en het alleen mogen gebruiken van de gegevens voor het doel Sectorrapportage Duurzame Zuivelketen. Zodra er overeenstemming is over de voorwaarden, kan de daadwerkelijke vragenlijst worden uitgezet.

5. De werkwijze voor berekening en dataverzameling van de indicatoren is geëvalueerd en is geoptimaliseerd voor toepassing voor alle ondernemingen, tijdens het opstellen van de sectorrapportage over 2014. De resultaten zijn gepresenteerd aan de klankbordgroep van sectorstakeholders.

6. Het protocol is definitief vastgesteld door accordering door de stuurgroep Duurzame Zuivelketen, na enkele specifieke verbeteringen en verduidelijkingen. 


\title{
2 Veel gebruikte termen
}

\author{
Duurzame energie \\ Alle energie uit bronnen die voortdurend worden aangevuld (CBS en RVO, 2015), bijvoorbeeld: zon, wind, \\ waterkracht, aardwarmte en biobrandstof. Met duurzame energie wordt binnen de Duurzame Zuivelketen \\ hetzelfde bedoeld als wat CBS definieert als hernieuwbare energie. Het gaat dus niet om de evaluatie of \\ iets duurzaam is. Doordat er geen fossiele brandstof wordt verbrand bij de opwekking van hernieuwbare \\ energie, heeft het vaak een lagere $\mathrm{CO}_{2}$-uitstoot dan fossiele energie (Van der Velden, 2014).
}

\section{Energiegebruik}

De opname van energie (chemisch, elektrisch, warmte, straling) die wordt omgezet in de andere vorm (beweging van mechanische delen of vloeistoffen, warmte, licht) met een directe nuttige toepassing. Energiegebruik en de detailleringen kunnen betrekking hebben op één energiesoort in één ketenschakel of op de hele zuivelketen.

\section{Energieverbruik}

Detaillering van energiegebruik, waarbij de chemische energie in een brandstof wordt omgezet naar een andere vorm, waarbij de brandstof wordt omgezet in emissies.

\section{Energieconsumptie}

Detaillering van energiegebruik, waarbij er sprake is van een saldering (de som van inkoop en productie minus de verkoop van energie).

\section{Emissiefactor}

Global Warming Potential van de productie en het gebruik van een vaste hoeveelheid product, waarbij in dit protocol een specifieke energiesoort het product is. Directe emissies en indirecte emissies worden meegenomen. Een verdere beschrijving is te vinden in paragraaf 4.6.2. Deze factor wordt uitgedrukt in kilogram koolstofdioxide-equivalenten ( $\mathrm{kg} \mathrm{CO}_{2}$-eq) (Blonk, Ponsioen, Scholten, 2009).

\section{Global Warming Potential}

Het effect van een emissie van broeikasgassen op de netto stralingsabsorptie in de troposfeer (radiative forcing), uitgedrukt in de equivalente koolstofdioxide-emissie over een vastgestelde tijdsperiode. In de berekening voor de Duurzame Zuivelketen worden alleen de belangrijkste broeikasgassen meegenomen: koolstofdioxide $\left(\mathrm{CO}_{2}\right)$, methaan $\left(\mathrm{CH}_{4}\right)$ en lachgas $\left(\mathrm{N}_{2} \mathrm{O}\right)$. Karakterisatiefactoren voor de omrekening van $\mathrm{CO}_{2}, \mathrm{~N}_{2} \mathrm{O}$ en $\mathrm{CH}_{4}$ naar $\mathrm{CO}_{2}$-equivalenten zijn 1 voor $\mathrm{CO}_{2}, 265$ voor $\mathrm{N}_{2} \mathrm{O}$ en 28 voor $\mathrm{CH}_{4}$, zoals vastgelegd in de laatst verschenen standaard van IPCC (2013) voor een tijdsperiode van 100 jaar. Er wordt geen rekening gehouden met de climate change feedback loop (IPCC, 2013) Veranderingen in de koolstofopname in de bodem (i.e. carbon sequestration) zijn niet meegenomen in deze studie.

\section{Hoeveelheid afgeleverde melk}

De totale massa melk die in een jaar bij de zuivelverwerkers is afgeleverd. Massa wordt uitgedrukt in kilogrammen $(\mathrm{kg})$ of tonnen $(\mathrm{t})$.

\section{Primair brandstofverbruik}

De hoeveelheid brandstof (massa of volume) die is verbruikt om een bepaalde hoeveelheid energie op te wekken. Met behulp van efficiëntiegetallen kunnen elektriciteit en warmte worden teruggerekend naar de hoeveelheid primaire brandstof. Met behulp van de verbrandingswarmten ${ }^{1}$ van de verschillende brandstoffen kunnen deze brandstofverbruiken worden omgerekend naar dezelfde eenheid die in Nederland gebruikelijk is: kubieke meters aardgasequivalenten (Van der Velden, 2014).

\footnotetext{
1 De verbrandingswarmte is de hoeveelheid energie, vaak warmte, die bij de verbranding van een bepaalde stof vrijkomt. Vaak wordt de 'onderste verbrandingswarmte' (low heating value) gebruikt als omrekengetal, waarbij de energie die wordt gewonnen door condensatie van de ontstane waterdamp niet wordt meegeteld.
} 


\section{Indicatoren en berekeningswijze}

\subsection{Doelen en indicatoren Duurzame Zuivelketen}

Onder het thema 'Klimaatneutraal ontwikkelen' vallen de subthema's broeikasgassen, duurzame energie en energie-efficiëntie. Voor ieder subthema is één doel vastgesteld waarvoor een hoofdindicator is vastgesteld. Bij deze doelen zijn ook ondersteunende of illustrerende indicatoren vastgesteld. In Tabel 3.1 staan de doelen en hoofdindicatoren weergegeven met alle ondersteunde indicatoren. Van deze indicatoren wordt de definitie en de methodiek in dit hoofdstuk uitgewerkt. De broeikasgas-indicatoren worden alleen uitgewerkt op het gebied van energiegebruik, terwijl de indicator de totale emissie weergeeft.

In dit hoofdstuk worden alle indicatoren beschreven. Daartoe worden eerst de relevante energiestromen in de zuivelketen beschreven in paragraaf 3.2. Vervolgens wordt de afbakening van de energie-indicatoren beschreven, in paragraaf 3.3, gevolgd door de details van de indicatoren en de rekenstappen voor de indicatoren over energie-efficiëntie en duurzaam energiegebruik, in paragraaf 3.4 en 3.5 respectievelijk. De afbakening van de broeikasgasindicator en de gedetailleerde beschrijving van de rekenmethode komen aan bod in paragraaf 3.6 en 3.7.

\section{Tabel 3.1}

Doelen en indicatoren bij subthema's van 'Klimaatneutraal ontwikkelen'

\begin{tabular}{|c|c|c|c|}
\hline Subthema & Doel & Indicatoren & Ondersteunende indicator \\
\hline Broeikasgassen & $\begin{array}{l}\text { Klimaatneutrale groei ten } \\
\text { opzichte van } 2011 \text { en } 20 \% \\
\text { reductie van broeikasgassen } \\
\text { ten opzichte van } 1990^{2} \text { in } \\
2020\end{array}$ & $\begin{array}{l}\text { Broeikasgasemissie van de } \\
\text { zuivelketen ( } \mathrm{Mton} \mathrm{CO}_{2} \mathrm{eq} \text { ) }\end{array}$ & $\begin{array}{l}\text { Intensiteit broeikasgasemissie op } \\
\text { melkveebedrijven }\left(\mathrm{kg} \mathrm{CO}_{2} / \mathrm{kg} \text { melk) }\right.\end{array}$ \\
\hline Energie-efficiëntie & $\begin{array}{l}\text { Verbetering energie-efficiëntie } \\
\text { van de zuivelketen van } \\
\text { gemiddeld } 2 \% \text { per jaar in } \\
2005-2020\end{array}$ & $\begin{array}{l}\text { Primair brandstofverbruik van } \\
\text { de zuivelketen }\left(\mathrm{m}^{3}\right. \\
\text { aardgasequivalenten } / 1.000 \mathrm{~kg} \\
\text { melk) }\end{array}$ & 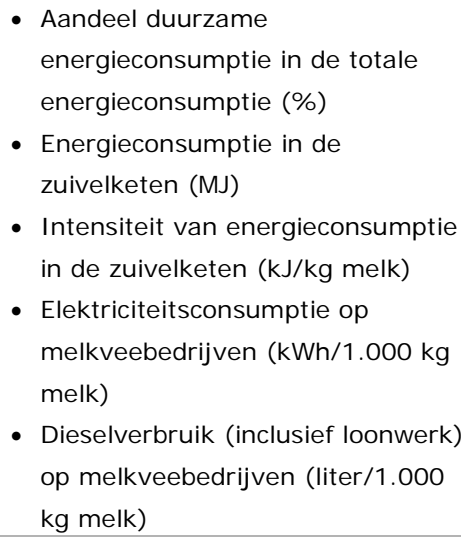 \\
\hline Duurzame energie & $\begin{array}{l}\text { Zestien procent productie van } \\
\text { duurzame energie in } 2020 \text { in } \\
\text { de zuivelketen }\end{array}$ & $\begin{array}{l}\text { Productie van duurzame } \\
\text { energie in het betreffende } \\
\text { jaar ten opzichte van de } \\
\text { geconsumeerde energie in de } \\
\text { zuivelketen (\%) }\end{array}$ & Productie van duurzame energie (PJ) \\
\hline
\end{tabular}

Bron: Reijs et al. (2015).

\footnotetext{
${ }^{2}$ Van het tweeledige doel van het subthema broeikasgasemissies wordt het doel van klimaatneutrale groei gemonitord met de indicator die in Tabel 3.1 is beschreven. Voor de monitoring van het doel van $20 \%$ reductie ten opzichte van 1990 wordt verkend of de landelijke Emissieregistratie kan worden gebruikt.
} 


\subsection{Beschrijving energiestromen}

In de drie geïdentificeerde ketenschakels wordt energie gebruikt en wordt duurzame energie geproduceerd. Om de berekeningsmethodes te beschrijven, moet eerst duidelijk zijn welke energiestromen er zijn in de zuivelketen. Hieronder worden de bijdrages aan energie-input en -output in de zuivelketen beschreven, die versimpeld weergegeven staan in Figuur 3.1 en uitgebreid in Bijlage 2.

In de ketenschakel melkveebedrijven wordt energie gebruikt in de vorm van elektriciteit, onder andere voor de melkmachine en reinigingsapparatuur en melkkoeling, aardgas voor de warmwatervoorziening en diesel voor het voeren en werkzaamheden op het land. Er wordt verder warmte gewonnen uit melk en met zonnecollectoren. Vergistingsinstallaties kunnen elektriciteit, warmte en gas opleveren.

Er wordt elektriciteit geproduceerd op sommige bedrijven met behulp van zonnepanelen, windturbines en vergistingsinstallaties. De energieproductie van een installatie wordt toegekend aan de melkveebedrijven als deze administratief onder de bedrijfsactiviteiten van het melkveebedrijf valt (zie paragraaf 4.3.2). Een installatie die op het land staat van een melkveebedrijf die niet onder het melkveebedrijf valt, wordt niet meegeteld.

In de ketenschakel melktransport gaat het zowel om transport van rauwe melk van boerderijen naar verwerkers (RMO, Rijdende Melk Ontvangst) als om het transport van rauwe melk en halffabricaten tussen productielocaties (Intra-transport). De grens tussen de ketenschakel logistiek en de andere schakels is niet haarscherp: de energie benodigd voor het vullen van de RMO kan namelijk zowel afkomstig zijn van de RMO zelf als van de melkveebedrijven waar de melk wordt opgehaald. Zo kan ook het legen van de RMO met energie van zowel de RMO als met energie van de zuivelverwerker plaatsvinden.

In de ketenschakel zuivelverwerkers wordt elektriciteit voor diverse toepassingen gebruikt. De verbruiken zijn het grootst in de zuivelproductie, maar ook elektriciteit van de uitgaande logistiek en kantoren wordt meegenomen. Aardgas en andere brandstoffen, evenals duurzame en niet-duurzame warmtebronnen, worden gebruikt om te verwarmen. Elektriciteit kan worden geproduceerd met behulp van zonnepanelen. Vergisting van reststoffen uit de melk kan elektriciteit, warmte en/of gas opleveren. 

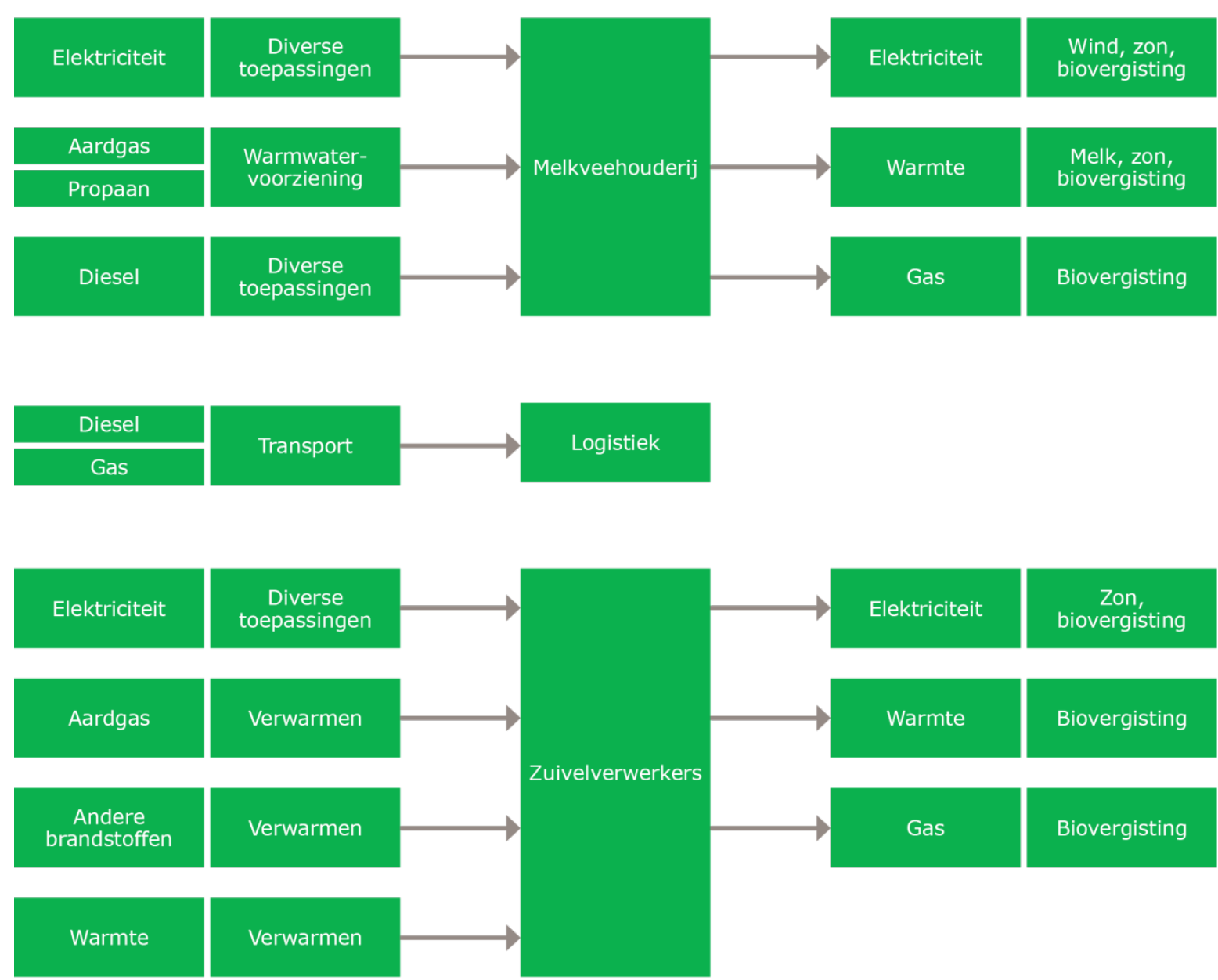

Figuur 3.1 Overzicht van energiestromen in de zuivelketen

\subsection{Afbakening}

Afbakening van de energie-indicatoren

De doelen en afspraken die met de energie-indicatoren worden geëvalueerd, focussen alleen op de partners in de zuivelketen (melkveebedrijven en melkverwerking (inclusief melktransport)) en niet op de toeleveringsketen. De indicatoren die voor deze doelen zijn gedefinieerd hebben dus een sectororiëntatie. Om die reden werd voor de sectorrapportage over 2014 de volgende afbakening gevolgd:

- De energiegebruiken en - producties van de drie schakels van de zuivelketen worden gebruikt in de energie-indicatoren, zonder de energiegebruiken van de toeleveringsketen mee te nemen.

- De energiegebruiken worden niet opgedeeld naar de verschillende producten (zuivel, vlees en energie) van de zuivelketen, want het totaal is relevant voor de afspraken en doelen in de sector: de Meerjarenafspraak energie-efficiëntie en Convenant Schone en Zuinige Agrosectoren.

Deze afbakening heeft echter ook nadelen: een melkveehouder kan namelijk door voer aan te kopen in plaats van zelf te verbouwen het energiegebruik in de keten volgens de huidige afbakening verlagen, omdat het dieselgebruik benodigd voor de teelt en transport van aangekocht voer niet mee wordt geteld. Deze zogenaamde afwenteling van energiegebruik vindt momenteel plaats in de melkveehouderij door de trend van intensivering. De resultaten op de energie-indicatoren zouden daardoor licht verbeteren voor de Nederlandse zuivelsector in de komende jaren, terwijl er netto niet minder energie wordt gebruikt.

Na overleg met het programmateam is er besloten om de indicatoren breder af te bakenen voor de sectorrapportage over 2015, om het effect van afwenteling te ondervangen. Afwenteling kan namelijk 
niet als verduurzamingsstrategie worden gezien en zou geen effect moeten hebben op de resultaten van de indicatoren. De energiegebruiken van de toeleveringsketen zullen in de sectorrapportage over 2015 worden meegeteld in het energiegebruik in de indicatoren.

De energiestromen die nu nog klein zijn maar waarvan wordt verwacht dat ze groeien, zijn in dit protocol opgenomen. Verder zullen voor de volledigheid de relatief beperkte energiegebruiken van kantoren en distributiecentra met ingang van de rapportage over 2015 voor zover mogelijk worden opgenomen. Het energiegebruik van ondersteunende diensten voor de melkveebedrijven, zoals boekhoudkantoren en dierenartsenpraktijken, is verwaarloosbaar, zodat het niet mee wordt genomen in de indicatoren.

Afbakening van de broeikasgasindicatoren

De methode van berekening van de broeikasgasemissies is gebaseerd op de 'cradle to factory gate'benadering van de IDF-standaard (IDF, 2015). De gehele zuivelketen wordt dus in kaart gebracht, inclusief de toeleveringsketen (productie, transport, verwerking van onder andere voer en kunstmest). Het effect van afwenteling van milieu-impact (bijvoorbeeld van voederproductie) is bij broeikasgasemissies groter dan bij energiegebruik, en kan dus sterker beperkt worden. Door de emissies van de toeleverende keten nauwkeurig te berekenen, kan de Duurzame Zuivelketen afgesproken en mogelijke verduurzamingsopties in de toeleveringsketens monitoren.

Dit protocol richt zich op de emissie ten gevolge van energiegebruik in de Nederlandse zuivelketen, die bestaat uit melkveebedrijven (inclusief loonwerk op deze bedrijven), logistiek en melkverwerking. Daarom worden in dit protocol de rekenstappen die worden gedaan met de energiebijdragen uit de zuivelketen beschreven (in paragraaf 3.6). De broeikasgasemissies van de toeleveringsketen en van niet-energiebijdragen worden opgenomen in de broeikasgasindicator, en zijn berekend volgens de methode die beschreven is in de sectorrapportage (Reijs et al., 2015).

De cradle-to-farmgate broeikasgasindicator wordt niet gebruikt voor de evaluatie van de $20 \%$ reductie ten opzichte van 1990. Om dit doel te evalueren lijkt de landelijke Emissieregistratie het meest geschikt omdat het doel is afgeleid van landelijke afspraken. De Emissieregistratie evalueert de ontwikkeling van het landelijke doel en heeft een referentie-emissie voor 1990. In Bijlage 5 wordt dit verder uitgelegd.

\section{Overeenkomst in afbakening}

Voor de sectorrapportage over 2014 (Reijs et al., 2015) zijn de afbakening van broeikasgasindicatoren en energie-indicatoren verschillend geweest: voor de broeikasgasindicatoren zijn de bijdrages van de toeleveringsketen meegenomen, terwijl ze voor de energie-indicatoren niet zijn meegenomen. Voor de sectorrapportage over 2015 zullen de energie-indicatoren wel de ketenbijdragen meenemen, en zal de afbakening van energie- en broeikasgasindicatoren dus overeenkomen.

\subsection{Subthema energie-efficiëntie}

\subsubsection{Doel en achtergrond}

Het doel in het subthema energie-efficiëntie is het verbeteren van de energie-efficiëntie van de Nederlandse zuivelketen met gemiddeld 2\% per jaar in de periode 2005 tot en met 2020. Deze doelstelling heeft zijn achtergrond in twee convenanten:

1. de MJA-afspraken van de zuivelsector ( $2 \%$ energie-efficiëntieverbetering) en

2. de afspraken van de primaire sectoren in het convenant Schone en Zuinige Agrosectoren ( $2 \%$ energiebesparing per jaar).

De Duurzame Zuivelketen heeft deze twee in 2014 samengevoegd tot een doelstelling over de hele keten, omdat zij synergievoordelen ziet tussen de melkveebedrijven en melkverwerking en als gehele keten daarop willen worden beoordeeld. 
De MJ A-afspraken worden gemaakt en uitgevoerd aan de hand van de Europese Energie-efficiëntie Richtlijn (Energy Efficiency Directive, EED). Eén van de verplichtingen voor grote bedrijven is om een energie-audit uit te voeren, zodat ze energie gaan besparen (één van de criteria is dat het bedrijf meer dan $250 \mathrm{fte}$ in dienst moet hebben). Bedrijven die deelnemen aan de Meerjarenafspraak energie-efficiëntie 2001-2020 (MJ A3) hoeven echter geen extra actie te ondernemen. Dat geldt dus voor alle zuivelverwerkers.

\subsubsection{Indicatoren}

De hoofdindicator, de energie-efficiëntie, wordt uitgedrukt als het primair brandstofverbruik in $\mathrm{m}^{3}$ aardgasequivalenten per $1.000 \mathrm{~kg}$ melk in het betreffende jaar. Ondersteunende indicatoren zijn 'het aandeel duurzame energieconsumptie in de totale energieconsumptie' (\%), 'de energieconsumptie in de zuivelketen' (MJ), 'de intensiteit van de energieconsumptie in de zuivelketen' ( $\mathrm{kJ}$ per kg melk), 'de elektriciteitsconsumptie op melkveebedrijven' (kWh/1.000 kg melk), 'dieselverbruik (inclusief loonwerk) op melkveebedrijven' (liter/1.000 kg melk). Zie Tabel 3.1.

De afstemming van deze indicatoren met EED- en MJA3-indicatoren is geëvalueerd. De EED geeft geen informatie over de berekeningswijzen van de energie-indicatoren. De MJ A3-rapportages gaan meer in detail: de energie-efficiëntie wordt geëvalueerd door een besparingspercentage uit te rekenen: de gerealiseerde energiebesparing wordt gedeeld door de som van het werkelijke gebruik en de gerealiseerde besparing (RVO, 2014).Om volgens deze definitie te kunnen rapporteren is het noodzakelijk om energiebesparende maatregelen te identificeren en het verwachte en gerealiseerde effect te kwantificeren. Verwachte en/of gerealiseerde effecten van besparingen zijn zeer moeilijk te kwantificeren in de melkveehouderij.

De definitie van energie-efficiëntie die wordt gehanteerd in dit rapport wijkt dus af van de MJAdefinitie van energie-efficiëntie. Met definitie uit dit protocol ontstaat inzicht in de mate waarin het fossiele brandstofverbruik als gevolg van activiteiten van de hele zuivelketen afneemt, niet in de mate waarin besparingen gerealiseerd worden.

\subsubsection{Methode}

Om de energie-efficiëntie te berekenen, wordt het primair brandstofverbruik van de zuivelketen vastgesteld en door de totale hoeveelheid afgeleverde melk gedeeld.

1. Alle energiegebruiken worden vastgesteld voor iedere soort, voor alle ketenschakels (vanaf de rapportage over 2015 inclusief de toeleveringsketen). Voor ieder energiegebruik wordt vastgesteld welk aandeel niet-hernieuwbaar is.

2. Het primair brandstofverbruik van alle energiegebruiken worden vastgesteld door de energiegebruiken te vermenigvuldigen met de primaire brandstoffactoren. De primaire brandstoffactoren worden jaarlijks vastgesteld op basis van de Nederlandse situatie. Primaire brandstoffactoren van hernieuwbare energie zijn nul, zodat hernieuwbare energie geen bijdrage heeft aan het primair brandstofgebruik.

3. Energie die aan derden (buiten de zuivelketen) wordt verkocht, wordt omgerekend naar de overeenkomstige hoeveelheid primair brandstofverbruik en van de ketenbijdragen primair brandstofgebruik afgetrokken. De zuivelketen produceert momenteel echter alleen duurzame energie, dat geen primair brandstofverbruik kent. Als er een correctie moet worden toegepast, dan wordt er aangenomen dat de uitgespaarde energie van de Nederlandse mix van opwekkingstechnologieën afkomstig is.

4. De ketenbijdragen primair brandstofverbruik worden gesommeerd over de keten.

5. Dit totaal wordt gedeeld door de hoeveelheid afgeleverde melk. 


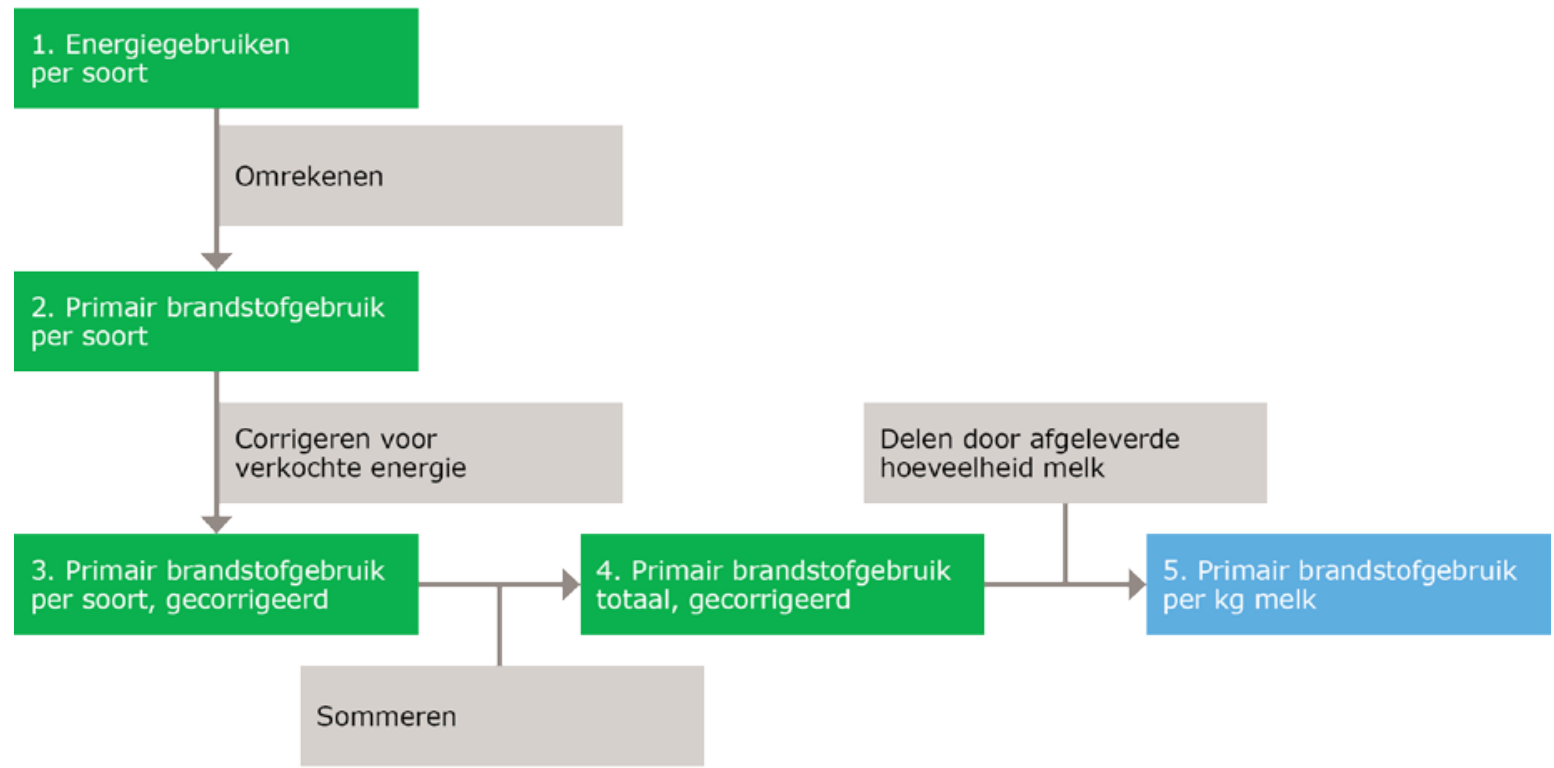

Figuur 3.2 Berekeningsmethode voor de hoofdindicator voor energie-efficiëntie

Ondersteunende indicatoren voor energie-efficiëntie

De berekening van ondersteunende indicatoren worden hieronder beschreven en afgebeeld in

Figuur 3.3 en Figuur 3.4:

1. Aandeel duurzame energieconsumptie in de totale energieconsumptie (\%)

De totale duurzame energieconsumptie en de totale energieconsumptie worden vastgesteld door het energiegebruik en inkoop op te tellen en daar verkoop van af te trekken, van alle soorten duurzame en niet duurzame energie, zonder de omrekening naar primaire brandstof, op basis van alle soorten energiegebruik, inkoop en verkoop. Deze worden op elkaar gedeeld.

2. Energieconsumptie in de zuivelketen (MJ)

De totale energieconsumptie wordt vastgesteld zoals beschreven in stap 6. Deze energieconsumptie wordt geïndexeerd, waarbij 2005 het referentiejaar is.

3. Intensiteit van energieconsumptie in de zuivelketen ( $\mathrm{kJ}$ per kg melk)

De energieconsumptie van stap 8 wordt gedeeld door de hoeveelheid afgeleverde melk voor het betreffende jaar. De energieconsumptie per $\mathrm{kg}$ melk van het betreffende jaar wordt geïndexeerd, waarbij 2005 het referentiejaar is.

4. Elektriciteitsconsumptie op melkveebedrijven ( $\mathrm{kWh} / 1.000 \mathrm{~kg}$ melk)

De elektriciteitsconsumptie wordt vastgesteld (inkoop - verkoop + eigen productie). Dit wordt gedeeld door de hoeveelheid afgeleverde melk.

5. Dieselverbruik (inclusief loonwerk) op melkveebedrijven (liter/1.000 kg melk)

Het directe dieselverbruik, door de melkveehouder zelf, wordt gedeeld door de hoeveelheid afgeleverde melk. Indirecte dieselverbruik door loonwerkers wordt ook gedeeld door de hoeveelheid afgeleverde melk. Deze bijdragen worden bij elkaar opgeteld. 


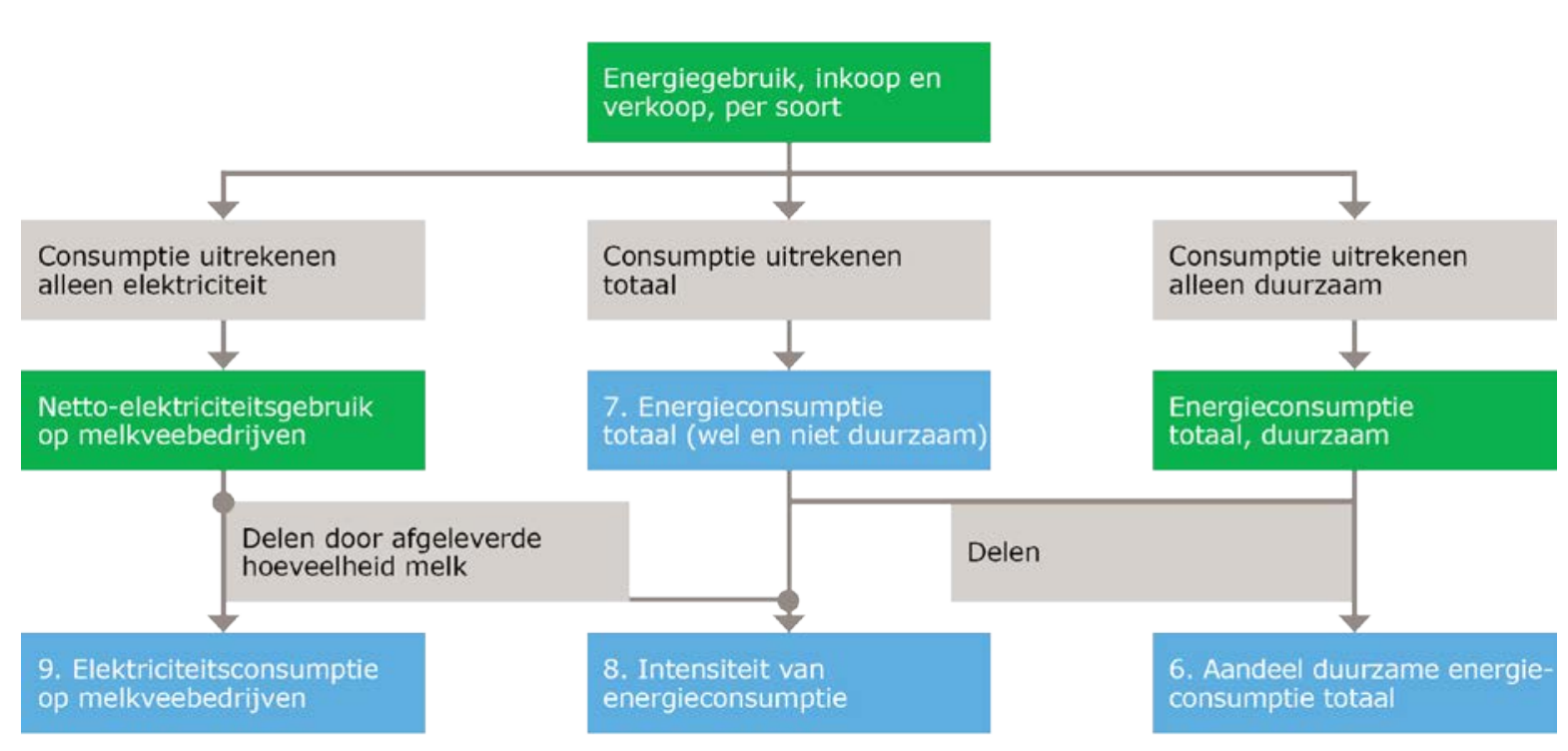

Figuur 3.3 Berekeningsmethode voor de eerste vier ondersteunende indicatoren voor energieefficiëntie

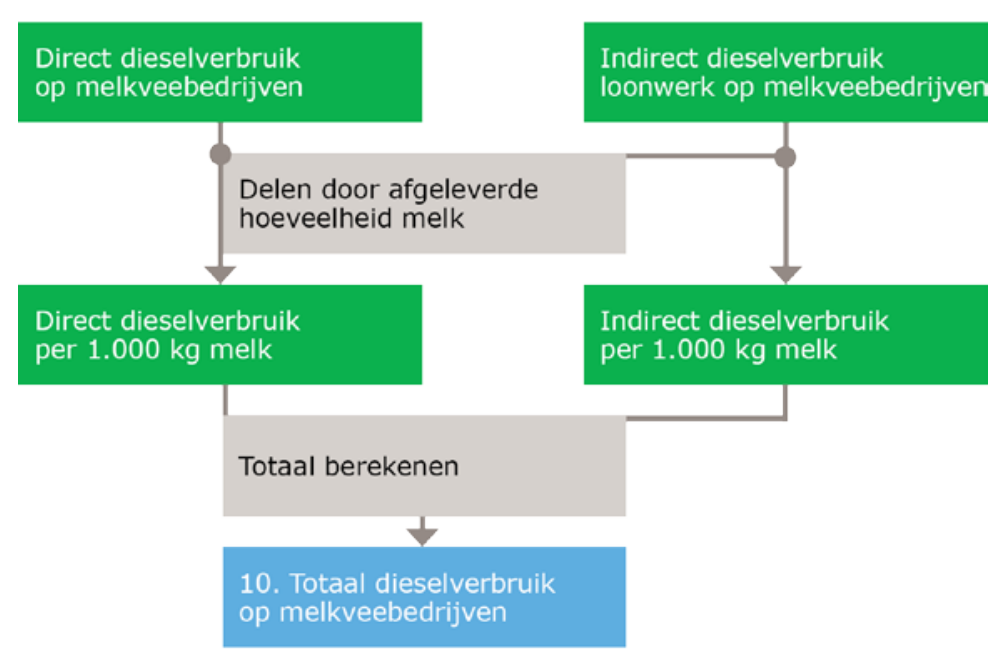

Figuur 3.4 Berekeningsmethode voor de indicator over dieselgebruik voor energie-efficiëntie

\subsection{Subthema duurzame energieproductie}

\subsubsection{Doel en achtergrond}

Het hoofddoel in het subthema duurzame energieproductie is het realiseren van een duurzame energieproductie gelijk aan of groter dan $16 \%$ van de totale energieconsumptie in de Nederlandse zuivelketen in 2020. Achterliggende gedachte is dat de zuivelketen wil laten zien dat zij haar verantwoordelijkheid neemt in de afspraken zoals gemaakt in het landelijke energieakkoord ( $14 \%$ duurzame energie in 2020) en dat de productie van duurzame energie kan bijdragen aan de andere doelstellingen van het thema als deze energie ook binnen de sector wordt gebruikt.

\subsubsection{Indicatoren}

De hoofdindicator is de verhouding van de duurzame energieproductie ten opzichte van de totale energieconsumptie van de zuivelketen in het betreffende jaar. De indicator wordt uitgedrukt in procenten, bijvoorbeeld: 'De duurzame energieproductie van de zuivelketen in 2016 was 12,3\% van 
de totale energieconsumptie van de zuivelketen.' De ondersteunende indicator is de totale duurzame energieproductie, uitgedrukt in PJ. Zie Tabel 3.1.

\subsubsection{Methode}

Om tot de verhouding tussen duurzame energieproductie en de totale energieconsumptie te komen worden deze energiehoeveelheden berekend op basis van de bijdrages van de individuele energiesoorten. Vervolgens wordt de verhouding bepaald (Figuur 3.5).

1. De totale energieconsumptie van de schakels in de zuivelketen worden vastgesteld en gesommeerd (vanaf de rapportage over 2015 inclusief de toeleveringsketen).

2. De duurzame energieproductie van de schakels in de zuivelketen worden vastgesteld en gesommeerd. De bijdrages van alle energiesoorten (verschillende brandstoffen, elektriciteit, enzovoort) worden hierbij omgerekend naar beschikbare energie (de hoeveelheid energie die de gebruiker kan consumeren) in J oule. Dit is ook de ondersteunende indicator.

3. Voor de hoofdindicator wordt de totale duurzame energieproductie op de totale energieconsumptie gedeeld en met 100 vermenigvuldigd.

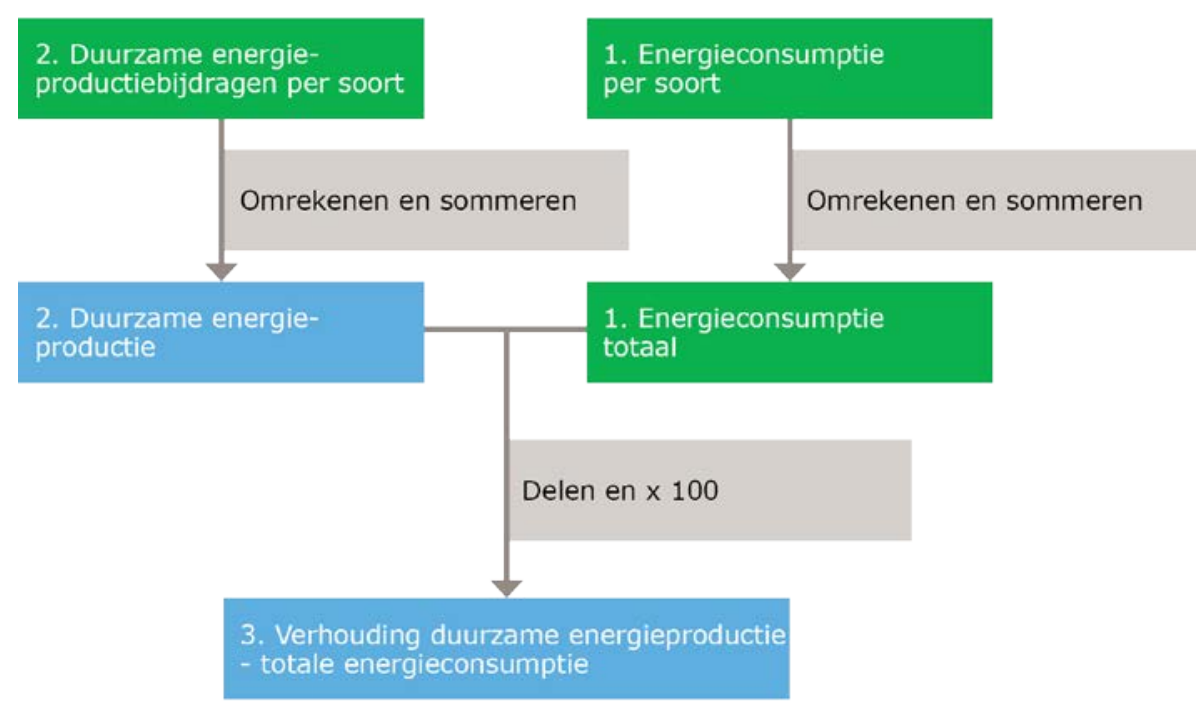

Figuur 3.5 Berekeningsmethode voor indicator duurzame energieproductie

\subsection{Subthema broeikasgasemissie}

\subsubsection{Doel en achtergrond}

De Duurzame Zuivelketen heeft als doel om de groei van Nederlandse Zuivelketen klimaatneutraal te realiseren. De Duurzame Zuivelketen heeft namelijk in het Plan van Aanpak voor de zuivelsector d.d. 1 juli 2013 (NZO en LTO Nederland, 2013) de afspraak gemaakt dat in 2020 geen nettostijging van broeikasgasemissie vanuit de zuivelketen heeft plaatsgevonden ten opzichte van de nulmeting (2011).

\subsubsection{Indicatoren}

De hoofdindicator is de broeikasgasemissie van de zuivelketen in het betreffende jaar. De indicator heeft als eenheid megaton $\mathrm{CO}_{2}$-eq. Deze totale emissie wordt opgebouwd uit de bijdragen van 
melkveebedrijven, logistiek en melkverwerkers. De ondersteunende indicator op dit subthema is de broeikasgasemissie per kilogram melk, met als eenheid $\mathrm{kg} \mathrm{CO}_{2}$-eq / kg melk. ${ }^{3}$ Zie Tabel 3.1.

\subsubsection{Methode}

De broeikasgasemissies ten gevolge van energie worden vastgesteld voor iedere emissiebron, per schakel van de Nederlandse zuivelketen (Figuur 3.1), en deze worden verwerkt in de hoofdindicator en de ondersteunende indicator.

1. De hoeveelheden ingekochte, geproduceerde en de verkochte energie wordt vastgesteld voor iedere energiesoort, fossiel en niet-fossiel, en de energieconsumptie wordt berekend met deze gegevens. De bijdrage van melkveebedrijven wordt gebaseerd op de broeikasgasemissie van individuele bedrijven uit de steekproef van het Informatienet.

2. De broeikasgasemissie ten gevolge van energie wordt voor iedere ketenschakel berekend, door de consumptie van iedere energiesoort te vermenigvuldigen met zijn emissiefactor, en de emissiebijdragen van de verschillende soorten per keten bij elkaar op te tellen.

3. De broeikasgasemissies ten gevolge van energie wordt opgeteld bij de buiten het protocol bepaalde emissies voor iedere ketenstap. Deze ketentotalen worden omgerekend naar de hoofdindicator en de ondersteunende indicator, zoals beschreven in Bijlage 6 .

De ontwikkeling ten opzichte van het doel wordt geëvalueerd door de procentuele verandering van de indicator ten opzichte van 2011 te berekenen. Er wordt voor de totale broeikasgasemissie onderscheid gemaakt tussen on-farm emissies en off-farm emissies. Alle emissies ten gevolge van energiegebruik zijn off-farm emissies met uitzondering van de emissie bij verbranding van conventionele diesel door de melkveehouder en de loonwerker. De $\mathrm{CO}_{2}$ die vrijkomt bij verbranding van biodiesel is kort voor gebruik door de groei van een energiegewas uit de atmosfeer gehaald en heeft geen netto-emissie. De productie van de diesel (conventioneel en biodiesel) heeft een off-farm emissie. De off-farm/on-farm opsplitsing wordt verduidelijkt in paragraaf 4.6.2.

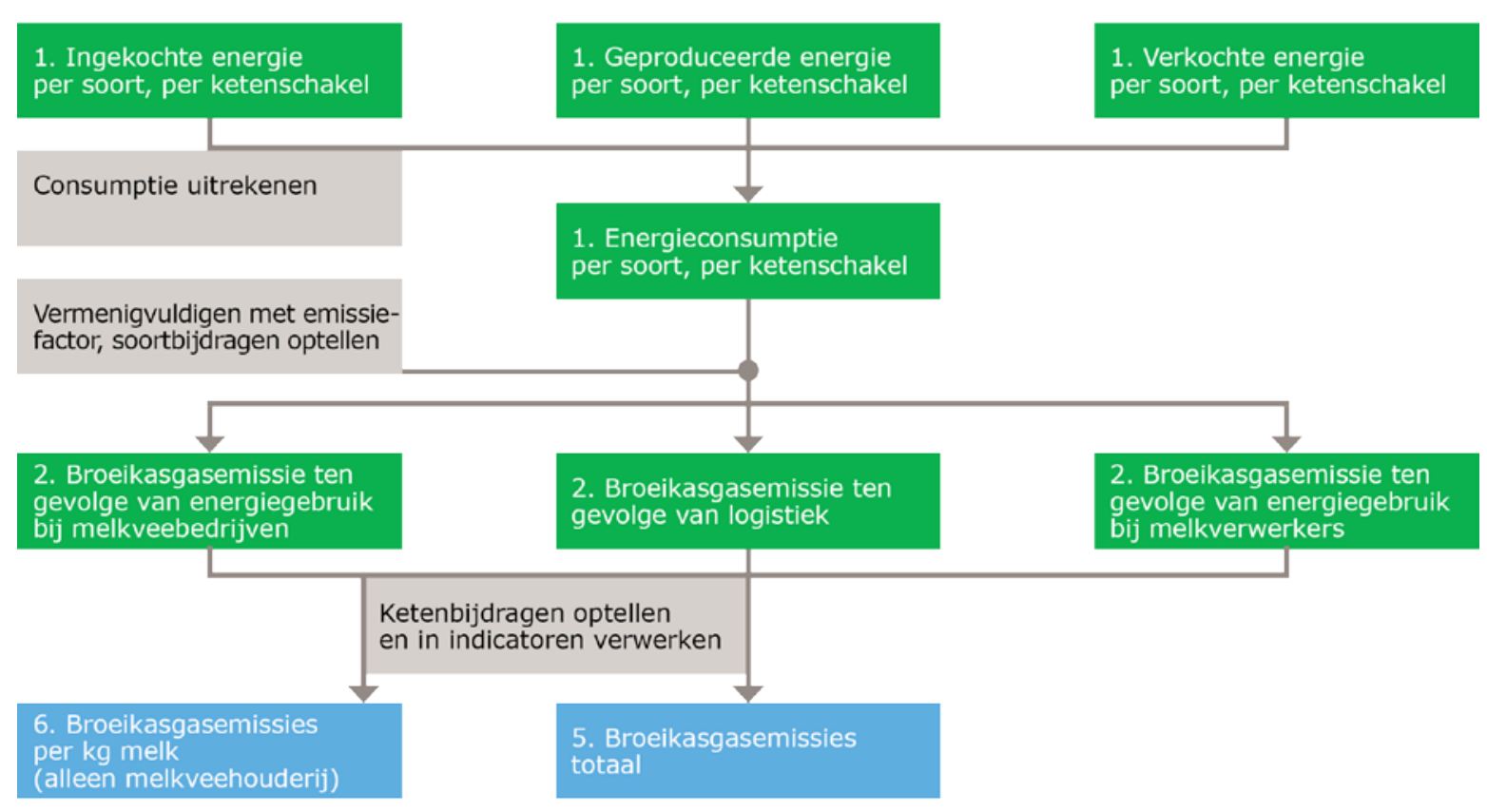

Figuur 3.6 Berekeningsmethode voor broeikasgasemissie-indicator

\footnotetext{
3 Hierbij is de voorkeur aan kg melk gegeven boven kg FPCM (fat and protein corrected milk) omdat de niet gecorrigeerde melk herkenbaarder is. Voor het vergelijken van individuele bedrijven zou het nauwkeuriger zijn om FPCM te gebruiken. $\mathrm{Bij}$ de hoofdindicator gaat het om totale broeikasgasemissie en is er geen onderscheid tussen FPCM en melk.
} 


\section{$4 \quad$ Databronnen en -gebruik}

\subsection{Inleiding}

Om de rekenstappen die in hoofdstuk 3 zijn beschreven uit te voeren zijn gegevens nodig. Om de resultaten betrouwbaarder en nauwkeuriger te maken dan in de eerdere sectorrapportages, zijn diverse potentiële databronnen verkend. In dit hoofdstuk wordt beschreven welke databronnen zijn gebruikt in het protocol, zoals dat is toegepast voor de monitoring over 2014 (Reijs et al., 2015), en op welke manier.

\subsection{Databronnen}

De databronnen die mogelijk kunnen worden gebruikt om de benodigde data te leveren, staan in Tabel 4.1 samengevat en zijn hieronder beschreven. Details en overwegingen hoe de verschillende benodigde data worden gebruikt voor de berekeningen, worden in de volgende paragrafen gegeven. In Tabel 4.1 wordt ook een vergelijking gemaakt met de gehanteerde databronnen in de eerdere sectorrapportages (tot en met 2013) en de mogelijke verbeterpunten op lange termijn (2015-2017). Deze verbeterpunten worden beschreven in hoofdstuk 5.

\section{Tabel 4.1}

Benodigde data en invulling met databronnen (KvK: kamer van koophandel, ABR: Algemeen bedrijven register)

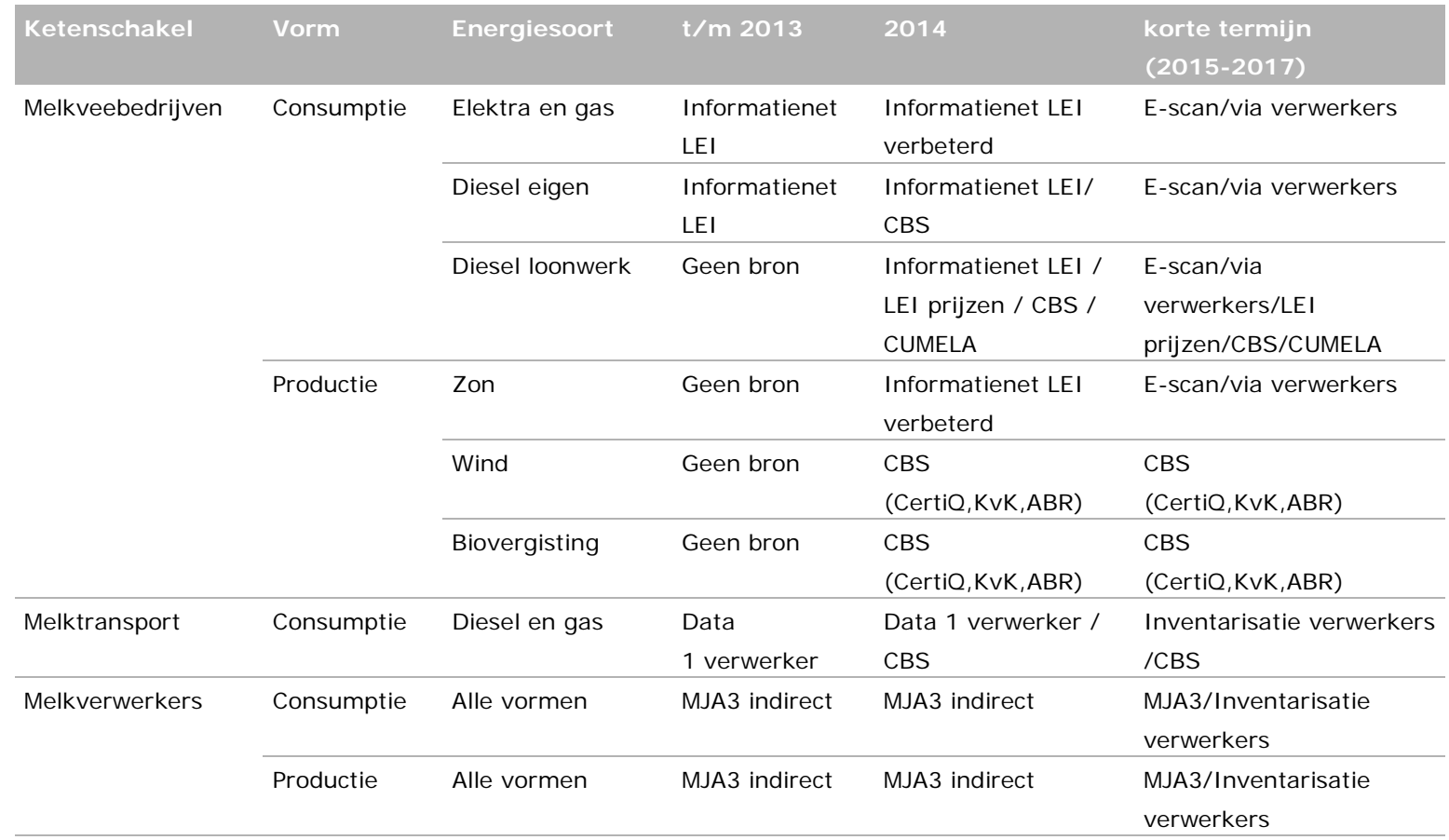

Bedrijveninformatienet van het LEI

Het Bedrijveninformatienet is een panel van 1.500 land- en tuinbouwbedrijven, visserij- en particuliere land- en tuinbouw. Alleen de heel kleine bedrijven zitten er niet in. De opgenomen bedrijven vertegenwoordigen bijna $95 \%$ van de totale agrarische productie. 
De landbouwtelling (CBS-Landbouwtelling) vormt het uitgangspunt voor het vaststellen van de steekproef voor het I nformatienet. Op basis van de meest recente landbouwtelling worden bedrijven ingedeeld in klassen (strata), die zijn gevormd op basis van het bedrijfstype en de economische omvang (op basis van Standaard Opbrengst (SO)). Voor elk stratum wordt vastgesteld hoeveel bedrijven in de steekproef moeten worden opgenomen.

Er worden gegevens over de bedrijfsvoering van individuele bedrijven verzameld, die ook worden gebruikt voor bedrijfseconomische onderzoeken. Deze gegevens worden ook in diverse duurzaamheidsonderzoeken toegepast omdat grondstof- en energiegebruiken in kaart worden gebracht.

In 2014 waren er 16.346 melkveebedrijven, waarvan er 278 zijn opgenomen in de berekeningen voor de sectorrapportage. Elk van die bedrijven staat model voor een aantal bedrijven uit de Landbouwtelling in dezelfde klasse van bedrijfstype (biologisch/niet-biologisch) en omvang (4 klassen op basis van SO). Om de gegevens uit de steekproef op te schalen naar de landelijke situatie, krijgt ieder bedrijf in het Informatienet een wegingsfactor die gelijk is aan het aantal bedrijven in de Landbouwtelling waarvoor dit bedrijf model staat (Van der Meer et al., 2013).

Agrarische prijzendatabase van het LEI

Het LEI verzamelt met medewerking van de toeleverende en verwerkende industrie en de handel al tientallen jaren de prijzen van de belangrijkste agrarische producten en productiemiddelen, waaronder de prijzen van diesel.

\section{MJ A3-rapport zuivelindustrie}

De Rijksdienst voor Ondernemend Nederland (RVO) rapporteert jaarlijks over het gebruik en de besparing van energie en over productie en inkoop van duurzame energie van de zuivelverwerkende industrie (RVO, 2015), om de Meerjarenafspraken energie-efficiëntie te evalueren aan de hand van de totalen voor de zuivelverwerkende industrie (voor zover zij deelnemen aan MJA3). Daarbij worden de gegevens uit de eigen administratie van de zuivelverwerkers gebruikt, terwijl er geen resultaten van individuele zuivelverwerkers worden getoond.

\section{Energiescan}

De Energiescan, ook wel E-scan genoemd, is een online vragenlijst voor melkveehouders die wordt uitgezet door melkverwerkers. In de Energiescan staan gedetailleerdere vragen over energie dan in het Bedrijveninformatienet van het LEI : energiegebruik en -productie, apparatuur, melkstaltype en verlichting. De eerste keer invullen vraagt een volledige inventarisatie, de daarop volgende jaren is slechts een update nodig. Door het gebruik van de Energiescan krijgt de melkveehouder meer inzicht in het energiegebruik op zijn bedrijf en hoe zich dit verhoudt tot andere bedrijven (benchmark). Ook geeft het programma adviezen over hoe het energiegebruik kan worden verlaagd. Het gebruik van de Energiescan is momenteel vrijwillig, al wordt dit door verschillende zuivelverwerkers wel gestimuleerd doordat het gebruik ervan bijvoorbeeld punten kan opleveren voor het verkrijgen van een duurzaamheidstoeslag op het melkgeld. De kans is groot dat de E-scan op termijn van meer bedrijven gegevens verzameld dan het Bedrijveninformatienet. De gegevens worden opgeslagen door zuivelverwerkers en zijn in een consistente structuur beschikbaar voor het LEI ten behoeve van de sectorrapportage.

\section{CUMELA}

CUMELA is de brancheorganisatie voor ondernemers in groen, grond en infra en behartigt daarmee ook de belangen van ondernemers in de agrarische loonwerksector. CUMELA inventariseert via de kengetallenvergelijking CUMELA Kompas Analyse de bedrijfseconomische ontwikkelingen in de sector. Jaarlijks doen bijna 500 bedrijven (in verschillende sectoren) hieraan mee. Vanuit de kengetallenvergelijking heeft CUMELA zicht op de brandstofkosten op loonwerkbedrijven en welk aandeel deze brandstofkosten uitmaken van de brutomarge of de omzet.

CertiQ

Dit bedrijf, dat ressorteert onder de RVO, certificeert energie die is opgewekt uit de duurzame bronnen zon, water, wind en biomassa. Ze zijn voor deze taak aangewezen door de overheid. De Garanties van 
Oorsprong (GvO's) die CertiQ elektronisch verstrekt, zijn in Nederland het enige geldige bewijs dat energie duurzaam is opgewekt. De producenten hebben dit bewijs nodig om subsidie te ontvangen, waardoor nagenoeg alle producenten hun gegevens met CertiQ delen. Certificaten die worden uitgegeven door CertiQ zijn verhandelbaar binnen Europa.

Centraal Bureau voor de Statistiek (CBS)

Het CBS verzamelt, bewerkt en publiceert allerlei statistieken ten behoeve van de overheid, de wetenschap en het bedrijfsleven. Het verzorgt onder andere de Landbouwtelling. Het CBS volgt de verduurzaming van de energieproductie in Nederland en rapporteert hier jaarlijks over in de publicatie Hernieuwbare energie in Nederland (CBS, 2015). Daarnaast levert het data aan de Rijksdienst voor Ondernemend Nederland voor het rapport Energie en Klimaat in de Agrosectoren (Moerkerken et al., 2014), waarin voor het bepalen van de windenergieproductie door de landbouw het principe 'windmolens op landbouwgrond' wordt gebruikt, zoals beschreven in het CBS-rapport Windenergie bij de landbouw (Segers, 2014).

\section{Emissieregistratie}

De emissieregistratie is een programma dat het Rijksinstituut voor Volksgezondheid en Milieu uitvoert in opdracht van het ministerie van Infrastructuur en Milieu (RIVM, 2015). De bij de emissieregistratie betrokken instituten verzamelen, beheren en rapporteren emissiedata, opdat de betrokken ministeries aan de nationale en internationale verplichtingen op het gebied van emissierapportages kunnen voldoen, waaronder de verplichting wat betreft broeikasgassen volgens het Kyoto-protocol en het Emission Trading Scheme (ETS). De broeikasgasemissies in Nederland worden, afhankelijk van de bron, gerapporteerd door verschillende sector-georiënteerde taakgroepen waar de betrokken instituten in geclusterd zijn.

\section{Zuivelverwerkers}

Verwerkers hebben een regierol in de keten en kunnen een rol spelen in de energiedataverzameling van de eigen ketenschakel, van het melktransport en van de melkveebedrijven. Zuivelverwerkers verzamelen zelf informatie over gebruik en productie van energie op de eigen verwerkingslocatie(s) om kosten en duurzaamheid te optimaliseren. Verwerkers kunnen een rol spelen bij het inzichtelijk maken van het brandstofverbruik bij het melktransport (RMO's). Ook zijn verwerkers actief om melkveehouders inzicht te laten krijgen in het eigen energiegebruik en de eventuele eigen energieproductie, bijvoorbeeld via een tool als de Energiescan. Elk jaar doen meer melkveehouders mee, maar er is geen structurele dekking van de sector. Verwerkers kunnen stimuleren dat meer melkveehouders de Energiescan gaan invullen.

\section{KringloopWijzer}

Een melkveehouder kan met behulp van de KringloopWijzer de mineralenkringlopen voor zijn bedrijf in beeld brengen. De tool berekent ook de broeikasgasemissie, onder andere uit het energiegebruik. Dit gebeurt echter nog weinig bedrijfsspecifiek (er hoeven geen gebruikte hoeveelheden elektriciteit, gas en/of diesel te worden ingevoerd), mede omdat de bijdrage van het energiegebruik aan de totale broeikasgasemissie op een melkveebedrijf maar beperkt is. Om het energiegebruik bedrijfsspecifiek mee te nemen zouden de resultaten van de energiescans in te lezen zijn in de KringloopWijzer. Dit is technisch goed mogelijk. Maar vanuit de duurzame zuivelketen (DZK) is momenteel geen prioriteit gegeven aan deze bedrijfsspecifieke energiebepaling in de KringloopWijzer, zodat deze op korte termijn (voorjaar 2016) geen onderdeel van de KringloopWijzer zal zijn. Het is dus denkbaar dat er een koppeling wordt gemaakt met de Energiescandatabase, zodat de detailinformatie over het energiegebruik ook beschikbaar is voor de Kringloopwijzer zonder dat dit extra inspanning vraagt van de veehouder. Voorlopig wordt er geen gebruik gemaakt van gegevens uit de kringloopwijzer voor de energiemonitoring.

\section{Energieleveren.nl}

Energieleveren. $\mathrm{nl}$ is een initiatief van de gezamenlijke netbeheerders en geeft inzicht in waar productie-installaties voorkomen en wat de capaciteit ervan is. De data worden bijeengebracht in het Productie Installatie Register (PIR) Het registreren van productie-installaties is van belang, omdat netbeheerders deze gegevens nodig hebben om het elektriciteitsnet goed te kunnen beheren. Het 
melden van productie-installaties is echter nog niet verplicht, waardoor niet duidelijk is hoe volledig het register is. Om die reden wordt van deze bron nog geen gebruik gemaakt.

ZuivelNL

ZuivelNL is de ketenorganisatie van de Nederlandse zuivelsector. Eén van de activiteiten die deze organisatie uitvoert is het verzamelen en publiceren van marktinformatie. Dit betreft onder andere informatie over de hoeveelheid afgeleverde melk aan zuivelverwerkers op jaarbasis.

Landbouwtelling

In de landbouwtelling wordt eens per drie jaar geïnventariseerd welke installaties voor duurzame energieproductie er op landbouwbedrijven voorkomen. Het laatste jaar waarin dit werd gevraagd betrof 2013. De landbouwtelling die in 2016 staat gepland zal de vereiste data voor de energiemonitoring niet meer gedetailleerder in kaart brengen, om de lasten voor de rapporterende melkveehouders beperkt te houden. De mogelijkheden om de landbouwtelling als databron te gebruiken zijn onderzocht en blijven dus voorlopig beperkt.

\subsection{Datagebruik Melkveebedrijven}

\subsubsection{Energie-inkoop en -gebruik melkveebedrijven}

\section{Elektriciteit}

De gegevens over elektriciteitsgebruik op de melkveebedrijven voor de sectorrapportage over 2014 zijn verzameld vanuit het Informatienet. Er is in de sectorrapportage over 2014 met terugwerkende kracht vanaf 2011 onderscheid worden gemaakt tussen groene en grijze ingekochte stroom. Verder wordt het energiegebruik in het Informatienet gecorrigeerd voor privégebruik. Als er energieproductie is mét eigen gebruik, zoals bij zonne-energie, dan kan het interne gebruik van zonne-energie worden berekend als productie minus verkoop.

Gas

Het conventionele gasgebruik op de melkveebedrijven bestaat uit aardgas en propaangas. De gegevens voor deze gebruiken worden voor de rapportage over 2014 overgenomen vanuit het Informatienet. Het duurzame gasgebruik is vanaf 2013 gekwantificeerd in het Informatienet. Het bestaat uit zowel $\mathrm{CO}_{2}$-gecompenseerd aardgas als methaan gewonnen uit biomassa, die is opgewaardeerd tot aardgaskwaliteit. Er is geen duurzaam propaangas.

Diesel

Alle diesel die in Nederland wordt gebruikt is fossiele diesel waar een vaste hoeveelheid biodiesel is bijgemengd. Gebruik van $100 \%$ biodiesel is zeer uitzonderlijk. De gegevens over dieselgebruik van de melkveebedrijven worden verzameld vanuit het Informatienet. Het gebruik van biodiesel wordt vanaf 2014 berekend door het totale dieselverbruik te vermenigvuldigen met de bijgemengde fractie van biodiesel, analoog aan de aanpak van het CBS.

Het dieselverbruik van loonwerk werd tot de sectorrapportage van 2013 niet in kaart gebracht. Voor de sectorrapportages wordt het dieselverbruik van loonwerk als volgt geschat:

1. Via de bedrijfsvergelijking van CUMELA van loonwerkbedrijven zijn de kosten voor diesel en de netto omzet (exclusief zaaizaad en gewasbeschermingsmiddelen, kuilplastic) bekend per jaar, zodat per jaar het aandeel dieselkosten in de netto-omzet kan worden berekend.

2. Vanuit de loonwerkfacturen van melkveehouders zijn de kosten van het loonwerk per bedrijf bekend vanuit Informatienet, waarbij de kosten voor zaaizaad, gewasbeschermingsmiddelen en kuilplastic zijn geboekt op andere kosten posten (dan loonwerk). De loonwerkkosten per jaar worden vermenigvuldigd met de jaarspecifieke aandelen diesel met de dieselkosten uit loonwerk als resultaat.

3. De dieselkosten uit loonwerk worden gedeeld door de gemiddelde dieselprijs in een jaar, afkomstig uit de LEI-prijzendatabase om tot het dieselverbruik uit loonwerk in liters te komen.

4. Met de bijmengpercentages van het CBS wordt bepaald welk deel duurzaam is en welk deel conventioneel. 
De aanpak kan alleen op sectorniveau worden toegepast, omdat in een grote populatie melkveebedrijven afwijkingen elkaar uitmiddelen. Voor individuele bedrijven kan de genoemde werkwijze leiden tot afwijkingen, bijvoorbeeld bij inzet van een loonwerker met relatief lage loonwerktarieven kan het dieselverbruik uit loonwerk onderschat worden.

CUMELA Nederland kan een tabel opmaken met de brandstofkosten per brutomarge en per omzet, weergegeven voor de periode 2005-2014. De gegevens zijn gebaseerd op de deelnemers met een omzet van meer dan $67 \%$ in de veehouderij (gras- en maisteelt). Een kanttekening is dat loonwerkbedrijven zelf kiezen of ze meedoen aan de bedrijfsvergelijking, waardoor de resultaten niet representatief zouden kunnen zijn voor al het loonwerk voor de melkveebedrijven.

De auteurs van de Sectorrapportage Duurzame Zuivelketen zullen CUMELA in de conceptfase van iedere rapportage raadplegen bij het toelichten en verklaren van de trends die zichtbaar zullen zijn in het indirecte dieselverbruik om een correcte interpretatie te garanderen.

\subsubsection{Energieproductie en -verkoop melkveebedrijven}

Energieproductie met verkoop en eigen gebruik

Van de Informatienetbedrijven met productie van energie uit zonnepanelen is bekend hoeveel energie er is geproduceerd, en hoeveel er is geleverd aan het net. De productie wordt geverifieerd door de productie ook te berekenen via de geïnstalleerde capaciteit maal een normproductie (van 875 $\mathrm{kWh} / \mathrm{Wp}$ ), en door de eenmalig verkregen gegevens van LTO-Energie te gebruiken. Voor de financiële afrekening met de energieleverancier wordt de aan het net geleverde elektriciteit in perioden met overschotten (zomer) afgetrokken van de van het net afgenomen hoeveelheid elektriciteit in perioden met tekorten (winter). Voor de financiën is de verkoop dus netto nul, maar de daadwerkelijk gebruikte en verkochte hoeveelheden worden meegenomen in de berekeningen.

Energieproductie met verkoop en zonder eigen gebruik $\mathrm{Er}$ is doorgaans geen eigen gebruik van elektriciteit uit wind en co-vergisting door melkveebedrijven, zodat de energieproductie gelijk is aan de verkoop, omdat er middenspanning wordt geleverd en alleen laagspanning kan worden gebruikt.

De gegevens van elektriciteitsverkoop van windmolens en co-vergisting worden via het CBS verkregen. Het CBS kan productiegegevens van CertiQ met gegevens van de Kamer van Koophandel (KvK) en het Algemene Bedrijvenregister ( $A B R)$ combineren zoals hieronder beschreven:

1. Het CBS ontvangt gegevens per aansluiting van CertiQ over de hernieuwbare elektriciteitsproductie, het vermogen en de gesubsidieerde warmteproductie.

2. De aansluitingen die onder de melkveebedrijven vallen worden geselecteerd door de KvK nummers in de CertiQ data te koppelen met de KvK nummers in het ABR.

3. Uit het $A B R$ kunnen de gewenste bedrijfstypen worden geselecteerd, volgens de internationaal afgestemde standaard bedrijfsindeling waarin de hoofdactiviteit 'Fokken en houden van melkvee' wordt geselecteerd.

Een deel van de aansluitingen kon via ABR niet gekoppeld worden aan onderliggende sectoren. Van deze niet-gekoppelde aansluitingen kan een deel ook toebehoren aan de melkveehouderijsector. Dit deel is ingeschat op basis van de aanname dat het aandeel melkveebedrijven in de niet-gekoppelde aansluitingen gelijk is aan het aandeel melkveebedrijven in de gekoppelde aansluitingen. Omdat de gemiddelde omvang van de bruto-elektriciteitsproductie per aansluiting nogal verschilt tussen sectoren, waarbij de melkveebedrijven gemiddeld genomen een kleinere omvang hebben, is voor het geschatte aantal aansluitingen op melkveebedrijven binnen de niet-gekoppelde aansluitingen de aanname gedaan dat de bruto-elektriciteitsproductie per aansluiting gelijk is aan die op het gemiddelde gekoppelde melkveebedrijf. Vervolgens is de geschatte elektriciteitsproductie op melkveebedrijven binnen de niet-gekoppelde aansluitingen opgeteld bij de werkelijk aan melkveebedrijven gekoppelde elektriciteitsproductie en de som van beide betreft dus de totale elektriciteitsproductie op melkveebedrijven. De berekeningswijze is apart uitgevoerd voor elektriciteitsproductie uit wind en voor elektriciteitsproductie uit co-vergisting van mest. 
Het kan zijn dat melkveehouders ook participeren in windmolens en vergistingsinstallaties die onder andere nummers zijn geregistreerd. Deze energieproductiebijdragen worden niet meegenomen in deze aanpak. In theorie geldt dit ook voor zonnepanelen die administratief van het melkveebedrijf zijn gescheiden, zoals investeringen in zonnepaneelparken.

Deze aanpak leidt zeker tot onnauwkeurigheden bij windmolens die op landbouwgrond staan maar administratief onder een ander bedrijf vallen. Een alternatieve aanpak van het CBS voor het RVOrapport Energie en Klimaat in de Agrosectoren (Moerkerken et al., 2014), leidt op basis van het principe 'windmolens op landbouwgrond' tot grotere inschattingen van de agrarische windenergieproductie. Deze aanpak leidt tot een overschatting, terwijl de methode op basis van het ABR tot een onderschatting leidt. In de sectorrapportage over 2015 zullen de energie-indicatoren berekend worden met windenergieproductie op basis van zowel de eigendomsgegevens van het $A B R$ als het 'windmolens op landbouwgrond'-principe, en de resultaten van de verschillende uitgangspunten zullen naast elkaar worden gepresenteerd.

Energieproductie zonder verkoop met eigen gebruik Geproduceerd gas uit co-vergisting wordt meestal niet verkocht maar met een warmtekrachtkoppeling (wkk) omgezet in elektriciteit, dat wordt geleverd aan het net. De databron van deze elektriciteitsproductie staat beschreven in de eerste alinea van deze paragraaf. Deze productie wordt meegenomen in de indicator voor duurzame energieproductie.

Warmte uit melk en zonnecollectoren wordt niet meegenomen in de indicatoren voor duurzame energieproductie. Deze energieproductie wordt niet geregistreerd in het Informatienet en sinds 2014 niet in andere bronnen zoals het CBS. ${ }^{4}$ Verder is deze productie zeer beperkt, en wordt het op het bedrijf gebruikt.

De productie heeft overigens een indirect effect op de indicatoren voor energie-efficiëntie. De energieconsumptie van fossiele energiebronnen zou namelijk hoger zijn zonder duurzame energieproductie.

\subsection{Datagebruik Logistiek}

Melk

Voor de rapportage over 2014 wordt het dieselverbruik van enkele individuele zuivelverwerkers verzameld net als in eerdere jaren. Dit verbruik wordt geëxtrapoleerd naar de gehele zuivelsector. Voor de latere rapportages zullen alle zuivelverwerkers via een vragenlijst hun conventionele en alternatieve brandstofverbruik voor logistiek rapporteren. Het alternatieve brandstofverbruik kan gaan bestaan uit hernieuwbare brandstof zoals biodiesel of brandstoffen met een lagere Global Warming Potential, zoals LNG of CNG (respectievelijk Liquified en Compressed Natural Gas).

\section{Mest}

Het dieselverbruik van aanvoer van mest wordt berekend in het Informatienet waarbij constante parameters voor transportkilometers, brandstofverbruik en emissiefactoren worden aangenomen. Dit geldt voor aanvoer van een ander melkveebedrijf en van een andersoortig bedrijf. Het transport wordt vooral door mestdistributeurs uitgevoerd. Dit is consistent met Ecol nvent's cut-off/recycled content aanpak (zie Bijlage 4).

Het dieselverbruik van de afvoer van mest naar een bedrijf dat geen melkveehouderij is (maar bijvoorbeeld akkerbouwer), wordt toegekend aan de ontvanger volgens de cut-off/recycled content aanpak.

\footnotetext{
${ }^{4}$ Het CBS heeft ervoor gekozen zich beter aan internationale afspraken te houden en warmte uit melk niet langer als duurzame energie te rapporteren.
} 
In het geval dat mest door de melkveehouder of door de loonwerker wordt getransporteerd, valt een deel van het dieselverbruik door deze partijen onder het mesttransport, terwijl het niet kan worden afgesplitst van het totale verbruik door melkveehouders en loonwerkers. Dit leidt dus tot een overschatting van het totale dieselverbruik. Deze overschatting zal zeer beperkt zijn omdat transport door boeren en loonwerkers wettelijk beperkt is.

\subsection{Datagebruik Zuivelverwerkers}

Zuivelverwerkers rapporteren hun gebruik en productie van energie, zowel conventioneel als duurzaam, ten behoeve van de Meerjarenafspraak (MJA3) met de overheid over energieefficiëntieverbeteringen en de opwekking en inkoop van duurzame energie. Hiervoor stellen zij ieder jaar een rapport op (RVO, 2015). De specificatie naar verschillende vormen van energiegebruik (elektriciteit, gas, warmte en overig) worden overgenomen uit het gedetailleerdere rapport 'Monitoring duurzaamheidsdoelstellingen zuivelindustrie 2014' (Fugro, 2015). Voor de 'overige brandstoffen' in dit rapport, die een kleine bijdrage aan het totale energiegebruik vertegenwoordigen, wordt aangenomen dat er aardgas wordt gebruikt.

Voor de rapportage over 2015 zullen de zuivelverwerkers in een vragenlijst hun gespecificeerde energiegebruik en -productie rapporteren. Dit is haalbaar bevonden in de pilot met twee zuivelondernemers (zie Bijlage 4). Een dergelijke vragenlijst zal ook moeten verduidelijken wat 'overige brandstoffen' uit het rapport van Fugro zijn, en van welke bron duurzame energie is ingekocht, door naar de Garanties van Oorsprong te vragen.

\subsection{Omrekeningsfactoren}

\subsubsection{Primaire brandstoffactoren}

Primair brandstofverbruik werd in eerdere sectorrapportages in PJ gerapporteerd en zal nu in $\mathrm{m}^{3}$ aardgasequivalenten worden uitgedrukt. De primaire brandstoffactoren en onderste verbrandingswarmten die voor de berekeningen nodig zijn, zijn in het Informatienet geïmplementeerd.

Elektriciteit is een secundaire energiebron, omdat het opgewekt wordt uit primaire brandstoffen zoals steenkool en aardgas. Deze opwekking van elektriciteit in centrales gaat gepaard met verliezen, dus het rendement is kleiner dan 100. Het primair brandstofverbruik wordt herberekend volgens factoren die volgen uit jaarspecifieke rendementen van elektriciteitscentrales zoals gerapporteerd in het Protocol Energiemonitor Glastuinbouw (Van der Velden, 2014). Voor bijvoorbeeld het jaar 2013 wordt uitgegaan van een rendement van energiecentrales van 44,9\%. Dit betekent dat het elektriciteitsverbruik (secundair) op melkveebedrijven in 2013 nog vermenigvuldigd moet worden met de factor $100 / 44,9=2,23$ om te komen tot het primair brandstofverbruik uit elektriciteit.

Energieverbruik gebaseerd op de MJA3-rapportage voor de zuivelsector (RVO, 2015). In deze rapportage wordt het primair brandstofverbruik weergegeven, waarbij voor elektriciteit geldt dat het primaire verbruik is berekend door het secundaire verbruik te vermenigvuldigen met een jaaronafhankelijke (vaste) factor van 2,5. Het primair brandstofverbruik is herberekend volgens de jaarspecifieke rendementen van Van der Velden (2014). De factoren zullen regelmatig worden geactualiseerd, bijvoorbeeld wanneer er nieuwe cijfers zijn uit de energiemonitoring in de glastuinbouw. 
Tabel 4.2

Primaire brandstoffactoren van energiesoorten gebruikt in de zuivelketen

\begin{tabular}{|c|c|c|c|}
\hline Data & & Eenheid & Bron \\
\hline Primaire brandstoffactor elektriciteit (constante van MJA3) & 2,5 & - & RVO, 2015 \\
\hline Primaire brandstoffactor elektriciteit 2013 (illustratief) & 2,274 & - & Van der Velden, 2014 \\
\hline Primaire brandstoffactor aardgas & 31,65 & $\mathrm{MJ} / \mathrm{m}^{3}$ & Informatienet \\
\hline Primaire brandstoffactor propaan & 25,2 & $\mathrm{MJ} / \mathrm{m}^{3}$ & Informatienet \\
\hline
\end{tabular}

\subsubsection{Emissiefactoren}

Een emissiefactor is de broeikasgasemissie ten gevolge van de productie en het gebruik van een vaste hoeveelheid van een specifieke energiesoort. Binnen de Sectorrapportage wordt een 'cradle to gate'benadering toegepast, wat betekent dat alle emissies worden meegenomen van de oorsprong van de grondstoffen tot het moment dat zuivel (eindproducten) de fabriek van de melkverwerker verlaat. De LCA database Ecol nvent (versie 3.1) wordt gebruikt om emissiefactoren af te leiden. Deze database bevat procesmodellen van vele productieprocessen, die aan elkaar verbonden zijn.

De emissiefactor voor biodiesel had als eenheid $\mathrm{kg} \mathrm{CO}_{2}$-eq. $/ \mathrm{kg}$ en is met de dichtheid $(\mathrm{kg} / \mathrm{L})$ en onderste verbrandingswarmte (MJ/L) omgerekend naar $\mathrm{kg} \mathrm{CO}_{2}$-eq./MJ. Emissiefactoren voor elektriciteitsbronnen zijn omgerekend van $\mathrm{kg} \mathrm{CO}_{2}$-eq/ $\mathrm{kWh}$ naar $\mathrm{kg} \mathrm{CO}_{2}$-eq/MJ met de omrekenfactor van $3.6 \mathrm{MJ} / \mathrm{kWh}$.

Voor emissiefactoren van energiesoorten betekent de 'cradle to gate'-benadering dat zowel de directe emissies, bij bijvoorbeeld de verbranding van een fossiele brandstof, en de indirecte emissies, voor productie van de opwekkingsinstallatie of van de brandstof worden meegenomen. Emissiefactoren van hernieuwbare energiebronnen zijn niet nul, omdat emissies bij de productie van bijvoorbeeld een windmolen of van de productie van zonnepanelen ook wordt meegenomen. De factoren zullen regelmatig worden geactualiseerd, bijvoorbeeld wanneer een nieuwe versie van Ecol nvent wordt gepubliceerd.

Duurzame kapitaalgoederen zoals fabrieksinstallaties worden meegenomen bij deze emissiefactoren, omdat dit een compleet beeld geeft. Dit is een voortzetting van wat eerder is gedaan en het is een belangrijke bijdrage aan broeikasgasemissie van duurzame energie. Voor andere emissiefactoren buiten dit protocol, voor kunstmest en plastic, is dezelfde aanpak gevolgd.

\section{Tabel 4.3}

Emissiefactoren van energiesoorten gebruikt in de zuivelketen

\begin{tabular}{|c|c|c|c|}
\hline Data & & Eenheid & Bron \\
\hline On-farm (bij verbranding) & 0,0740 & $\mathrm{~kg} \mathrm{CO}$-eq./MJ & Ecolnvent 3.1 \\
\hline Emissiefactor biodiesel & 0,0612 & $\mathrm{~kg} \mathrm{CO}$-eq./MJ & Ecolnvent 3.1 \\
\hline On-farm (bij verbranding) & 0,0 & $\mathrm{~kg} \mathrm{CO}$-eq./MJ & Geen fossiele emissie \\
\hline Emissiefactor elektriciteit grijs & 0,1844 & $\mathrm{~kg} \mathrm{CO}$-eq./MJ & Ecolnvent 3.1 \\
\hline Emissiefactor elektriciteit groen & 0,0117 & $\mathrm{~kg} \mathrm{CO}$-eq./MJ & Ecolnvent 3.1 \\
\hline Emissiefactor elektriciteit uit zonnepanelen & 0,0278 & $\mathrm{~kg} \mathrm{CO}{ }_{2}$-eq./MJ & Ecolnvent 3.1 \\
\hline Emissiefactor aardgas & 0,06759 & $\mathrm{~kg} \mathrm{CO}$-eq./MJ & Ecolnvent 3.1 \\
\hline
\end{tabular}




\section{$5 \quad$ Verbeterpunten voor de lange termijn}

\subsection{Verbeteringen in doelstellingen}

De Duurzame Zuivelketen focust in haar doelstellingen rond het subthema duurzame energie op het vergroten van de productie van energie uit hernieuwbare bronnen als wind, zon en mest (die duurzaam worden genoemd). De auteurs adviseren daarom om de term 'duurzame energie' in de doelen en indicatoren te vervangen door 'hernieuwbare energie'.

\subsection{Energiestromen bij de melkveebedrijven}

Om de energiestromen bij melkveebedrijven vollediger en nauwkeuriger in beeld te krijgen, zijn verschillende verbeteringen mogelijk. Het gaat hierbij om de volgende punten:

Eigendomsverhoudingen rond wind en covergisting verduidelijken

De inschatting van de energieproductie uit wind en co-vergisting op melkveebedrijven kan worden verbeterd door ook te kijken naar de achterliggende eigendomsverhoudingen bij wind en co-vergisting op 'energiebedrijven'. Dit kan op drie verschillende manieren worden opgelost. Er moet onderzocht worden wat haalbaar en het meest efficiënt is.

Optie 1 via CBS-data

De methode waarbij productiegegevens van CertiQ via de KvK-nummers worden gekoppeld aan het $A B R$, waaruit vervolgens de energieproductie kan worden bepaald die gekoppeld is aan bedrijven in de categorie 'Fokken en houden van melkvee', heeft als kanttekening dat eigendomsverhouding bij windmolens en co-vergistingsinstallaties complex kunnen zijn. Vaak worden voor windmolens en covergistingsinstallaties aparte bedrijven opgericht die dan weer eigendom zijn van één of vaak meerdere andere bedrijven uit dezelfde of juist verschillende sectoren. In het ABR zullen deze bedrijven meestal gekenmerkt worden als 'energiebedrijf'. Als melkveebedrijven participeren in dit soort energiebedrijven, dan wordt de energieproductie van die energiebedrijven in de huidige methode in z'n geheel niet toegerekend aan de melkveehouderij. Dit kan verbeterd worden door bij de toedeling ook te kijken naar de achterliggende eigendomsverhoudingen van 'energiebedrijven' waar soms wel informatie over beschikbaar is in het ABR, al vermoedt het CBS dat dit vrij complex is en ook niet in alle gevallen mogelijk is door incomplete gegevens.

Optie 2: via Energiescan

De inschatting van de energieproductie uit wind en co-vergisting op melkveebedrijven is naast het bij punt 1a. genoemde ook te verbeteren door gebruik van gegevens uit de Energiescan. Naast informatie over het verbruik van energie (zie verbeterpunt 2), wordt in de Energiescan ook gevraagd naar de productie van duurzame energie in de vorm van elektriciteit (uit zowel wind, biomassa als zon) en gas. Deze informatie kan ook gebruikt worden voor het inschatten van de energieproductie op melkveebedrijven. Een verbetering van de Energiescan die hierbij noodzakelijk is, is dat er een betere toelichting wordt gegeven over welke productie van duurzame energie een melkveehouder wel en welke hij niet mag meenemen. Stel dat een melkveehouder bijvoorbeeld participeert in een windmolenpark, dan is nu niet duidelijk welk deel van de energieproductie van dat windpark hij dan aan zijn eigen bedrijf mag toerekenen, waarbij de kans groot is dat melkveehouders daar heel verschillend mee omgaan. Daarnaast zouden de volgende voorwaarden moeten worden ingevuld voor het gebruik van data uit de Energiescan in de sectorrapportage:

- De Energiescan moet verder uitgerold zijn onder melkveehouders. Daarbij is het belangrijk dat een groter aantal melkveehouders ieder jaar de tool gaat invullen.

- De melkveehouders waarvan in een bepaald jaar de Energiescans beschikbaar zijn, moeten representatief zijn voor de gehele melkveehouderij. Dit kan getoetst worden door het vergelijken 
van kenmerken van de bedrijven waarvan een Energiescan beschikbaar is met bronnen waarin die kenmerken voor de hele populatie melkveebedrijven beschikbaar zijn.

- De data moet betrouwbaar zijn, dus er moet sprake zijn van enige controle en borging. Voor FrieslandCampina geldt dat er sinds zomer 2015 controle plaatsvindt door Qlip (organisatie gericht op borging van kwaliteit en voedselveiligheid in de Nederlandse zuivelketen).

- De verzamelde Energiescan-data moet in één database beschikbaar gesteld kunnen worden voor onderzoeksdoeleinden. Binnen de zuivel worden de Energiescans van de leden/leveranciers van de verschillende zuivelverwerkers al verzameld in één database. Het moet echter worden onderzocht in hoeverre deze database geschikt is voor onderzoeksdoeleinden.

Optie 3: via vragenlijst.

Zuivelondernemingen kunnen de duurzame energie productie ook gaan opvragen bij de aangesloten melkveehouders door middel van enkele extra vragen in de vragenlijst die naar zuivelverwerkers gaat (zie Bijlage 4), aangevuld met GvO-informatie van de melkveebedrijven. Daarbij zullen ook de voorwaarden van een goede en representatieve dekking en betrouwbare gegevens moeten worden ingevuld. Waarschijnlijk is een deel van deze informatie al beschikbaar en zal een aanzienlijk deel van de melkveehouders bereid zijn deze informatie te delen.

Energiegebruik uit Energiescan

Een mogelijkheid om de monitoring op termijn te verbeteren is om de gegevens over energiegebruik te gaan gebruiken die via de Energiescan worden verzameld als aanvulling op de steekproef van het Informatienet: via de Energiescan kunnen gegevens van meer bedrijven worden verzameld, zodat een completer beeld ontstaat. De huidige groep bedrijven die aan de Energiescan meedoet, is echter mogelijk nog niet representatief voor de melkveehouderijsector. Bij de overweging om de Energiescan te gebruiken voor energiegebruik gelden dezelfde voorwaarden als genoemd bij punt 1b, waar borging van de datakwaliteit een belangrijk aandachtspunt is.

Momenteel zijn in de Energiescan gegevens beschikbaar over het gebruik van elektriciteit, aardgas, propaangas en stookolie. Voor elektriciteit en aardgas wordt ook vastgelegd welk deel van afgenomen energie (voor zowel elektriciteit als gas) duurzaam geproduceerd is.

In de Energiescan ontbreekt op dit moment nog het verbruik van diesel, zowel direct verbruik door de melkveehouder als indirect dieselverbruik via inzet van loonwerkers. Om alle energiestromen op het melkveebedrijf met de Energiescan in beeld te kunnen brengen, is een uitbreiding van de tool noodzakelijk. Plannen voor het uitbreiding van de Energiescan met het dieselverbruik zijn ondertussen gemaakt door de zuivelindustrie.

Op de langere termijn is het voor de betrokken partijen te overwegen om de Energiescan-data op te slaan in de database van de Kringloopwijzer, en verdere integratie tussen energiemonitoring en mineralenmonitoring na te streven. Dit heeft voordelen binnen en buiten de sectorrapportage.

Verbeteringen op lange termijn

Omdat in de huidige monitoring alleen de meest voorkomende vormen van duurzame energie meegenomen, wordt er aanbevolen om op termijn andere vormen van duurzame energie ook te gaan monitoren. Deze energiestromen hebben een duidelijke definitie en een goede databron nodig om hun effect te vertalen naar de indicatoren. De productie en het (eigen) gebruik op melkveebedrijven van deze andere vormen van duurzame energie zou kunnen worden geregistreerd in het Informatienet of in de Energiescan als deze als bron voor de sectorrapportage wordt gebruikt.

Nieuwere vormen van duurzame energie waaraan gedacht kan worden zijn:

- onderscheid maken naar twee duurzame aardgasalternatieven: biogas enerzijds, dat uit een biologisch vergistingsproces komt, en groengas anderzijds, dat $\mathrm{CO}_{2}$ gecompenseerd conventioneel aardgas is

- warmte uit co-vergisting

- warmte, gas en elektriciteit uit mono-vergisting (alleen mest)

- warmte uit zonnecollectoren

- verduurzaamd propaangas: zowel $\mathrm{CO}_{2}$ gecompenseerd gas als gas uit een biologische bron zou in de toekomst beschikbaar kunnen zijn. 


\subsection{Energiestromen bij het melktransport}

Het diesel- en gasverbruik van het melktransport kan beter in kaart worden gebracht door van meer zuivelverwerkers een inschatting van het verbruik te verzamelen. Deze verzameling kan worden uitgevoerd via een vragenlijst aan verwerkers, mogelijk in combinatie met vragen over de energiestromen in de ketenschakels melkveehouderij en zuivelverwerking.

\subsection{Energiestromen bij de melkverwerkers}

Om de energiestromen bij de zuivelverwerkers vollediger en nauwkeuriger in beeld te krijgen, zijn verschillende verbeteringen mogelijk:

Breng de consumptie van door melkveehouders geproduceerde energie in kaart Breng in beeld welk deel van de gebruikte duurzame energie in de zuivelverwerking geproduceerd is bij eigen leden/leveranciers. Dit kan worden gedaan door bij de verwerkers te monitoren hoeveel GvO's zij aankopen van eigen leden/leveranciers. De aard van duurzame energie kan namelijk behoorlijk verschillen. Bij het gebruik van duurzame elektriciteit in de zuivelketen kan deze duurzame elektriciteit daadwerkelijk zijn geproduceerd in Nederland en mogelijk zelfs binnen de zuivelketen, maar het kan ook zo zijn dat dit 'grijze' elektriciteit betreft welke door aankoop van buitenlandse GvO's (van bijvoorbeeld Noorse waterkrachtcentrales die al lang bestonden) is vergroend. Gerichte aankoop van in eigen land of zelfs binnen de eigen sector geproduceerde duurzame energie vergroot de vraag en stimuleert hiermee een verdere verhoging van de productie van duurzame energie.

Verzamel meer details over de energieconsumptie Verzamel voor de Sectorrapportage Duurzame Zuivelketen informatie op een lager aggregatieniveau, in plaats van op sectorniveau via de MJA-rapportages. Daarmee kan inzicht worden verkregen in de componenten van de totale productie van duurzame energie (welke energiesoorten worden geproduceerd en via welk productiemiddel). De verbetering kan worden gerealiseerd door het uitzetten van de vragenlijst onder individuele zuivelverwerkers die in het kader van dit project is ontwikkeld (Zie Bijlage 4), of door te onderzoeken of de detailinformatie die zuivelverwerkers aanleveren ten behoeve van de MJA-rapportages aan RVO ook beschikbaar kan worden gesteld ten behoeve van de Sectorrapportage Duurzame Zuivelketen.

Verzamel gegevens over meer melkverwerkers

Breng de energiestromen in de gehele zuivelverwerking vollediger in beeld, waarbij ook de energiestromen bij zuivelverwerkers die niet aan de MJ A deelnemen mee worden genomen. Gegevens over het energiegebruik en de energieproductie bij zuivelverwerkers zijn momenteel gebaseerd op de jaarlijkse MJ A-Sectorrapportages Zuivelindustrie. Deelname aan de MJA is vrijwillig, waardoor de gegevens uit de MJA-rapportages niet alle zuivelverwerking omvat in Nederland, maar wel het overgrote deel (>98\%). De vragenlijst voor de zuivelverwerkers kan ook hier een rol spelen.

\subsection{Uitgevoerde en toekomstige verbeteringen}

Doordat dit protocol is opgesteld en bij de sectorrapportage over 2014 is gevolgd, zijn de belangrijkste verbeteringen bereikt, met name door een duidelijk gedefinieerde afbakening voor de energieindicatoren, een expliciete beschrijving van de rekenstappen en nieuwe databronnen voor dieselgebruik door loonwerk en voor duurzame energieproductie. Deze zijn grotendeels doorgevoerd in de sectorrapportage over 2014. Het protocol is recent bijgesteld om berekeningen van de indicatoren in de sectorrapportage van 2015 consistenter en duidelijker te maken, en om het draagvlak voor de indicatoren op de langere termijn zeker te stellen. Deze verbeteringen zijn beschreven in hoofdstuk 3 en 4 .

Gedurende 2016 zullen verdere verbeteringen worden gerealiseerd: een belangrijke verbetering zal worden bereikt door de vragenlijst voor de melkverwerkers verder goed af te stemmen op de 
datavraag en de mogelijkheden van de melkverwerkers. Verder zullen er andere stappen vooruit worden gezet als de data uit de Energiescan op de juiste manier kan worden gebruikt. Dit wordt momenteel onderzocht. Met de Energiescan of met de vragenlijst voor de melkverwerkers worden de eigendomsverhoudingen rond duurzame energieproductie verduidelijkt. De andere verbeteringen die in dit hoofdstuk zijn benoemd zullen op de langere termijn belangrijker worden, en zouden nog niet moeten worden geprioriteerd.

Voor zowel de al doorgevoerde en geplande verbeteringen als voor de aanbevolen verbeteringen geldt dat de kwaliteit van de indicatoren het sterkst wordt beïnvloed door de gebruikte inputdata. Het LEI en de Duurzame Zuivelketen zullen blijven samenwerken om de kwaliteit van de data te optimaliseren. De auteurs adviseren in deze context het protocol actueel te houden. 


\section{Literatuur en websites}

\section{Literatuur}

Blonk, H., T. Ponsioen en J. Scholten, 2009. $\mathrm{CO}_{2}$-voetafdruk: rekenmethode voor tuinbouwketens, Uitgever en plaats onbekend

CBS en RVO, 2015. Protocol Monitoring Hernieuwbare Energie. Herziening 2015. Publicatienummer: RVO-ool 2012/BR-DUZA, Utrecht: RVO

CBS, 2015. Hernieuwbare Energie in Nederland 2014. Den Haag: Centraal Bureau voor de Statistiek Fugro, 2015. Monitoring duurzaamheidsdoelstellingen zuivelindustrie 2014. Rapport M150727b. Leidschendam: Fugro GeoServices / EcoData.

IDF (International Dairy Federation), 2015. A common carbon footprint approach for dairy, The IDF guide to standard life cycle assessment methodology. Bulletin of the International Dairy Federation; issue 479. Brussels: IDF.

Harmelink, M., L. Bosselaar, J. Gerdes, R. Segers en M. Verdonk, 2013. Berekening van de $\mathrm{CO}_{2^{-}}$ emissies, het primair fossiel energiegebruik en het rendement van elektriciteit in Nederland. Den Haag: Centraal Bureau voor de Statistiek

Meer, R.W. van der, H.B. van der Veen en H.C.J. Vrolijk, 2013. Sample of Dutch FADN 2011: Design principles and quality of the sample of agricultural and horticultural holdings. LEI report 2013-064. Den Haag: LEI Wageningen UR.

Moerkerken, A., T. Gerlagh, G. de Jong en D. Verhoog, 2014. Energie en klimaat in de Agrosectoren. Publicatienummer: 2AGRO1406. Utrecht: Rijksdienst voor Ondernemend Nederland

NZO en LTO Nederland, 2013. Kansen voor de zuivelketen na 2015: verantwoord blijven ontwikkelen binnen maatschappelijke randvoorwaarden. Nederlandse Zuivelorganisatie en LTO Nederland: plan van aanpak voor de zuivelsector d.d. 1 juli 2013

Reijs, J.W., G.J. Doornewaard en A.C.G. Beldman, 2013a. Sectorrapportage Duurzame Zuivelketen. Nulmeting in 2011 ten behoeve van realisatie van de doelen. LEI-rapport 2013-013. Den Haag: LEI Wageningen UR.

Reijs, J.W., G.J. Doornewaard en A.C.G. Beldman, 2013b. Sectorrapportage Duurzame Zuivelketen. Prestaties 2012 in perspectief. LEI-rapport 2013-056. Den Haag: LEI Wageningen UR.

Reijs, J.W., G.J. Doornewaard, J.H. Jager en A.C.G. Beldman, 2014. Sectorrapportage Duurzame Zuivelketen. Prestaties 2013 in perspectief. LEI-rapport 2014-033. Den Haag: LEI Wageningen UR.

Reijs, J.W., G.J. Doornewaard, J.H. Jager en A.C.G. Beldman, A.C.G., 2015. Sectorrapportage Duurzame Zuivelketen; Prestaties 2014 in perspectief. LEI-rapport 2015-126. Wageningen: LEI Wageningen UR.

RVO (Rijksdienst voor Ondernemend Nederland), 2014. Methodiek Energie-efficiency MJ A3

RVO (Rijksdienst voor Ondernemend Nederland), 2015. MJ A-Sectorrapport 2014. Kenmerk 1235678/TDL/158007. Utrecht: Rijksdienst voor Ondernemend Nederland

Seegers, R., 2014. Windenergie bij de landbouw. Kenmerk: 6018510004 X-42. Den Haag: Centraal Bureau voor de Statistiek

Velden, N.J.A. van der, 2014. Protocol Energiemonitor Glastuinbouw. Versie tot en met 2013. LEIrapport 2014-025a. LEI Wageningen UR, Wageningen

Vellinga, Th.V., H. Blonk, M. Marinussen, W.J. van Zeist, I.J.M. de Boer en D. Starmans, 2013. Methodology used in FeedPrint: a tool quantifying greenhouse gas emissions of feed production and utilization, Report 674, Lelystad: Wageningen UR Livestock Research.

\section{Websites}

Duurzame Zuivelketen, 2015, Visie, http://www.duurzamezuivelketen. nl/visie, laatst geraadpleegd op 4 december 2015.

Ecol nvent, 2015a, Ecoinvent 3.1, http://www. ecoinvent.org/database/ecoinvent-version-3/ecoinvent31/ecoinvent-31. html, laatst geraadpleegd op 4 december 2015.

Ecol nvent, 2015b, Allocation cut-off by classification,_http://www. ecoinvent. org/database/ecoinventversion-3/system-models-in-ecoinvent-3/cut-off-system-model/allocation-cut-off-byclassification.html, laatst geraadpleegd op 4 december 2015. 
RIVM (RijksI nstituut Volksgezondheid en Milieu), 2015, De Emissie registratie,

http://www. emissieregistratie. nl/erpubliek/content/explanation.nl. aspx, laatst geraadpleegd op 4 december 2015 .

ZuivelNL, 2015, homepage, http://www.zuivelnl.org/\#, laatst geraadpleegd op 4 december 2015. 


\title{
Bijlage 1 Leden van stakeholdergroepen
}

\author{
Klankbordgroep \\ I da Smit (Rijkdienst voor Ondernemend Nederland, RVO) \\ Reinout Segers en Andre Meurink (Centraal Bureau voor de Statistiek, CBS) \\ Menno Douma (Land- en Tuinbouw Organisatie Nederland, LTO) \\ Marjolein de Kreij (Partico) \\ Greet Ruitenberg (Ruitenberg Advies) \\ Sanne Dekker (FrieslandCampina) \\ Michel de Haan (Wageningen UR) \\ Martijn Root (Ministerie van Economische Zaken) \\ Hans Verkerk (CUMELA) \\ Programmateam \\ Harry Kager (programmaleider) \\ Marjolein de Kreij \\ Arnoud Smit

\section{Stuurgroep} \\ Werner Buck, voorzitter stuurgroep Duurzame Zuivelketen \\ Jeroen Elfers, NZO \\ Tjeerd de Groot, NZO \\ Geert Hartlief, NZO \\ Toon van Hoof, LTO Nederland \\ Margo Meijerink, LTO Nederland \\ Kees Romijn, LTO Nederland \\ Leo van Sijll, NZO \\ Petra Tielemans, management Duurzame Zuivelketen
}




\section{Bijlage 2 Overzicht Energiestromen}

Dit overzicht is in dit project opgesteld. De nummering in het overzicht kan discussie faciliteren.

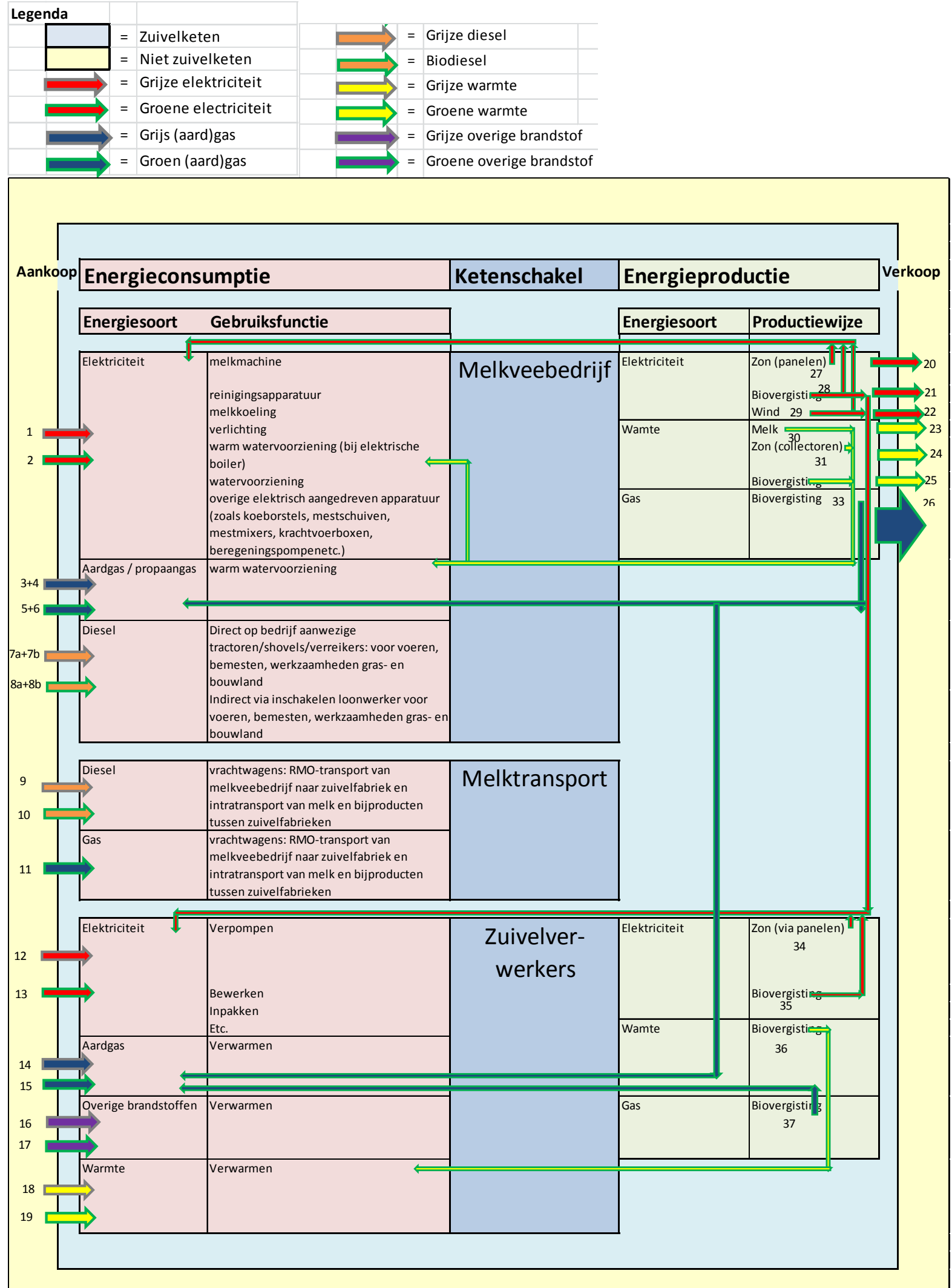




\section{Bijlage 3 Overzichtstabel indicatoren en rekenmethoden}

\begin{tabular}{|c|c|c|c|}
\hline Subthema duurzame energie & Indicator & Eenheid & Methode \\
\hline \multirow[t]{3}{*}{$\begin{array}{l}\text { Doel: } 16 \% \text { productie van duurzame } \\
\text { energie in } 2020 \text { in de zuivelketen }\end{array}$} & \multirow{2}{*}{$\begin{array}{l}\text { Indicator: Duurzame energieproductie } \\
\text { ten opzichte van de totale } \\
\text { energieconsumptie van de zuivelketen in } \\
\text { het betreffende jaar }\end{array}$} & $\%$ & $\begin{array}{l}\text { 1. De totale energieconsumpties van de schakels in de zuivelketen worden vastgesteld en gesommeerd } \\
\text { (vanaf de rapportage over } 2015 \text { inclusief de toeleveringsketen). }\end{array}$ \\
\hline & & & $\begin{array}{l}\text { 2. De duurzame energieproducties van de schakels in de zuivelketen worden vastgesteld en } \\
\text { gesommeerd. De bijdrages van alle energiesoorten (verschillende brandstoffen, elektriciteit, etc.) } \\
\text { worden hierbij omgerekend naar beschikbare energie (de hoeveelheid energie die de gebruiker kan } \\
\text { consumeren) in Joule. Dit is ook de ondersteunende indicator. }\end{array}$ \\
\hline & $\begin{array}{l}\text { Ondersteunende indicator: Totale } \\
\text { duurzame energieproductie }\end{array}$ & PJ & $\begin{array}{l}\text { 3. Voor de hoofdindicator wordt de totale duurzame energieproductie op de totale energieconsumptie } \\
\text { gedeeld en met } 100 \text { vermenigvuldigd. }\end{array}$ \\
\hline Subthema energie-efficiëntie & Indicator & Eenheid & \\
\hline \multirow{7}{*}{$\begin{array}{l}\text { Doel: Het verbeteren van de energie- } \\
\text { efficiëntie van de zuivelketen met } \\
\text { gemiddeld } 2 \% \text { per jaar in de periode } \\
2005 \text { tot en met } 2020 \text {. }\end{array}$} & \multirow[t]{5}{*}{$\begin{array}{l}\text { Indicator: Het primair brandstofverbruik } \\
\text { in } \mathrm{m}^{3} \text { aardgasequivalenten per } \mathrm{kg} \text { melk in } \\
\text { het betreffende jaar }\end{array}$} & $\%$ & $\begin{array}{l}\text { 1. Alle energiegebruiken worden vastgesteld voor iedere soort, voor alle ketenschakels. Voor ieder } \\
\text { energiegebruik wordt vastgesteld welk aandeel niet-hernieuwbaar is (vanaf de rapportage over } 2015 \\
\text { inclusief de toeleveringsketen). }\end{array}$ \\
\hline & & & $\begin{array}{l}\text { 2. De primaire brandstofverbruiken van alle energiegebruiken worden vastgesteld door het niet- } \\
\text { hernieuwbare aandeel te vermenigvuldigen met de primaire brandstoffactoren. Deze worden jaarlijks } \\
\text { vastgesteld op basis van de Nederlandse situatie. }\end{array}$ \\
\hline & & & $\begin{array}{l}\text { 3. Als er niet-hernieuwbare energie wordt verkocht, dan zal deze verkoop worden omgerekend naar de } \\
\text { overeenkomstige hoeveelheid primair brandstofverbruik en van de ketenbijdragen primair } \\
\text { brandstofgebruik afgetrokken. Bij deze correctie wordt aangenomen dat de uitgespaarde energie van de } \\
\text { Nederlandse mix van opwekkingstechnologieën afkomstig is. De zuivelketen produceert momenteel } \\
\text { echter alleen duurzame energie, dat geen primair brandstofverbruik kent. }\end{array}$ \\
\hline & & & 4. De ketenbijdragen primair brandstofverbruik worden gesommeerd over de keten. \\
\hline & & & 5. Dit totaal wordt gedeeld door de hoeveelheid afgeleverde melk. \\
\hline & $\begin{array}{l}\text { Ondersteunende indicator: het } \\
\text { elektriciteitsgebruik op melkveebedrijven }\end{array}$ & $\begin{array}{l}\mathrm{kWh} / 1000 \mathrm{~kg} \\
\text { melk }\end{array}$ & $\begin{array}{l}\text { 6. De elektriciteitsconsumptie op melkveebedrijven ( } \mathrm{kWh} / 1000 \mathrm{~kg} \text { melk): De elektriciteitsconsumptie } \\
\text { wordt vastgesteld (inkoop - verkoop + eigen productie). Dit wordt gedeeld door de hoeveelheid } \\
\text { afgeleverde melk. }\end{array}$ \\
\hline & $\begin{array}{l}\text { Ondersteunende indicator: Het } \\
\text { dieselverbruik, zowel direct als indirect }\end{array}$ & $\begin{array}{l}\text { liter/1000 kg } \\
\text { melk }\end{array}$ & $\begin{array}{l}\text { 7. Dieselverbruik, zowel direct als indirect (liter/1000 kg melk): Het directe dieselverbruik uit het } \\
\text { Informatienet wordt gedeeld door de hoeveelheid afgeleverde melk. Indirecte dieselverbruik is het } \\
\text { verbruik door loonwerkers. Dit wordt afgeleid van gegevens van CUMELA, zoals beschreven in paragraaf }\end{array}$ \\
\hline
\end{tabular}


4.3.1. Dit wordt vervolgens gedeeld door de hoeveelheid afgeleverde melk.

Ondersteunende indicator: consumptie

van energie in het betreffende jaar ten

opzichte van 2005

Ondersteunende indicator: consumptie

van energie in het betreffende jaar ten

opzichte van 2005

Ondersteunende indicator: Consumptie

van duurzame energie ten opzichte van de

totale energieconsumptie

\section{Subthema oroeikasgasemissie}

Doel: klimaatneutrale groei ten opzichte

van 2011 en $20 \%$ reductie van

ndicator

Indicator: De broeikasgasemissie van de zuivelketen in het betreffende jaar

broeikasgassen ten opzichte van 1990 in

2020

8. Consumptie van energie in het betreffende jaar ten opzichte van 2005 (MJ): De totale

energieconsumptie wordt vastgesteld door het energiegebruik en inkoop op te tellen en daar verkoop

van af te trekken, van alle soorten duurzame en niet duurzame energie, zonder de omrekening naar

primaire brandstof. Het energiegebruik van het betreffende jaar wordt geïndexeerd, waarbij 2005 het referentiejaar is.

kJ per kg melk 9. Consumptie van energie per $\mathrm{kg}$ melk in het betreffende jaar ten opzichte van 2005 ( $\mathrm{kJ}$ per $\mathrm{kg}$ melk):

De energieconsumptie van stap 8 wordt gedeeld door de hoeveelheid afgeleverde melk voor het betreffende jaar. De energieconsumptie per kg melk van het betreffende jaar wordt geïndexeerd waarbij 2005 het referentiejaar is.

10. Consumptie van duurzame energie ten opzichte van de totale energieconsumptie (\%): De totale duurzame energieconsumptie wordt vastgesteld en gedeeld door de totale energieconsumptie van stap

Eenheid Method

$\mathrm{Mt} \mathrm{CO}_{2}$-eq

1. De hoeveelheden ingekochte, geproduceerde en de verkochte energie wordt vastgesteld voor iedere energiesoort, fossiel en niet-fossiel, en de energieconsumptie wordt berekend met deze gegevens. De bijdrage van melkveebedrijven wordt gebaseerd op de broeikasgasemissie van individuele bedrijven uit de steekproef van het Informatienet.

2. De broeikasgasemissie ten gevolge van energie wordt voor iedere ketenschakel berekend, door de consumptie van iedere energiesoort te vermenigvuldigen met zijn emissiefactor, en de emissiebijdragen van de verschillende soorten per keten bij elkaar op te tellen.

\section{Ondersteunende indicator:}

Broeikasgasemissie per $\mathrm{kg}$ melk in het

betreffende jaar $\mathrm{kg} \mathrm{CO}{ }_{2}$ eq/

$\mathrm{kg}$ melk
3. De broeikasgasemissies ten gevolge van energie wordt opgeteld bij de buiten het protocol bepaalde emissies voor iedere ketenstap. Deze ketentotalen worden omgerekend naar de hoofdindicator en de ondersteunende indicator, zoals beschreven in Bijlage 6 . 


\section{Bijlage 4 Opzet pilot met zuivelverwerkers}

Met 2 zuivelverwerkers, FrieslandCampina en CONO Kaasmakers, heeft een pilot plaatsgevonden waarin de mogelijkheid om relevante data over energiegebruik en - productie in de keten te verzamelen via zuivelverwerkers is verkend. De opzet van de pilot was als volgt:

1. Uitwerken van een vragenlijst in Excel door projectteam.

2. Toesturen van de vragenlijst naar beide verwerkers met de vraag deze in te vullen zonder verder toelichting.

3. Bespreken ervaringen bij het invullen van de vragenlijst in een gezamenlijke bijeenkomst met het volgende programma:

a. Welkom, kennismaking voor zover nodig, toelichting op project Verbeteren energiemonitoring Duurzame Zuivelketen totaal, toelichting op onderdeel pilot met verwerkers

i. Delen van de ervaringen van de spreadsheet tot nu toe. Vragen hierbij:

ii. Hoe vond je de benadering/het verzoek (per mail) om de spreadsheet in te vullen. Was duidelijk wat er van je gevraagd werd?

iii. Wat is de algemene indruk van de spreadsheet?

iv. Hoe lang ben je bezig geweest met het invullen van de spreadsheet?

v. Hoe lang ben je bezig geweest met de dataverzameling?

vi. Wat vind je van de gebruikersvriendelijkheid?

vii. Welke overige opmerkingen en vragen heb je op dit moment?

b. Gezamenlijk doorlopen van de spreadsheet. Per vraag steeds checken of deze duidelijk is en of de vraagstelling logisch is. Kan het beter/duidelijker/makkelijker?

c. Afsluitende vragen:

i. Mis je nog vragen?

ii. Hoe kan de spreadsheet het beste worden uitgezet in de toekomst?

iii. Is het format (Excel) werkbaar?

iv. Hoe kan de gebruiksvriendelijkheid worden verbeterd?

d. Afsluiting 


\section{Bijlage 5 Monitoring doelstelling ' $20 \%$ reductie ten opzichte van 1990'}

In dit protocol wordt alleen de broeikasgasindicator beschreven die voor de doelstelling 'klimaatneutrale groei ten opzichte van 2011' kan worden gebruikt. Voor het beoordelen van de doelstelling ' $20 \%$ reductie ten opzichte van 1990' wordt verwezen naar de data en berekeningsmethodiek van de Emissieregistratie.

De Duurzame Zuivelketen neemt bij de beoordeling van het doel 'klimaatneutrale groei ten opzichte van 2011' de broeikasgasemissies in haar toeleveringsketen mee. Dit is een bewuste keuze om te voorkomen dat de emissies afgewenteld kunnen worden op andere sectoren, met name in het geval dat melkveehouders de voerproductie uitbesteden. Ook wordt er bewust voor gekozen om de emissie van verwerking en melktransport mee te nemen omdat de Duurzame Zuivelketen synergievoordelen ziet tussen de melkveebedrijven en melkverwerking als het gaat om emissiereductie als gevolg van hernieuwbaar energiegebruik.

Om de realisatie van de doelstelling '20\% reductie ten opzichte van 1990' te beoordelen, wordt aanbevolen om de systematiek van de Emissieregistratie te volgen, omdat deze systematiek ook wordt gebruikt om te beoordelen of Nederland als geheel haar doelstellingen realiseert. De landelijke Emissieregistratie wordt uitgevoerd om landelijke emissieafspraken te evalueren en is opgebouwd uit sectorbijdragen. De Emissieregistratie focust op de emissies waar een sector direct verantwoordelijk voor is. Alleen de emissies die plaatsvinden op de bedrijven zelf meegenomen, en wordt niet gekeken naar de toeleverende of verwerkende keten. Een voordeel van de methode van de Emissieregistratie is dat bij het optellen van directe emissies van verschillende landen of sectoren dubbeltellingen worden voorkomen. De cradle-to-gate benadering wijkt van deze systematiek af.

Uit de (voor 2014 voorlopige) resultaten van de Emissieregistratie kon worden opgemaakt dat de land- en tuinbouw in 2014 ruim 13\% bijdroeg aan de totale broeikasgasemissies in Nederland. Het aandeel van de Nederlandse land- en tuinbouw in de $\mathrm{CO}_{2}$-emissies is beperkt $(<5 \%)$, het aandeel in de overige broeikasgassen (+/-60\%) juist groot. De emissie van broeikassen uit de land- en tuinbouwsector is ten opzichte van 1990 met $26 \%$ gedaald voor $\mathrm{CO}_{2}, 11 \%$ voor methaan $\left(\mathrm{CH}_{4}\right)$ en $42 \%$ voor lachgas $\left(\mathrm{N}_{2} \mathrm{O}\right)$. De daling van methaanemissie in de landbouwsector wordt met name veroorzaakt door een afname van de dieraantallen en een afname van de productie van dierlijke mest en methaanemissie per koe. De daling van de lachgasemissie in de landbouwsector kent verschillende oorzaken te weten: afname van dieraantallen, minder gebruik van zowel kunstmest als dierlijke mest per hectare en een lagere $\mathrm{N}$-excretie per dier door een lager eiwitgehalte in het voer (Emissieregistratie broeikasgassen).

De melkveehouderij heeft een bijdrage geleverd aan deze dalingen, met name in de emissies van methaan en lachgas. Het is op dit moment nog niet mogelijk om in de resultaten van de Emissieregistratie de bijdrage van de melkveehouderij goed uit te splitsen. Voor volgende rapportages zal worden verkend of en hoe deze uitsplitsing kan worden gemaakt. 


\section{Bijlage 6 Samenvatting broeikasgasberekeningen}

\section{B6.1 Samenvattende rekenwijze}

De Nederlandse zuivelketen focust op melk en afgeleide producten. Melkveebedrijven zijn onderling te vergelijken met de indicator 'broeikasgasemissies per kg melk'. Omdat de melkveebedrijven naast melk ook vlees produceren, is toerekening van de milieubelasting aan verschillende producten (allocatie) dus nodig. Voor toewijzing van de milieubelasting tussen melk en vlees is de allocatie gebaseerd op de energiehuishouding van de koe zoals beschreven door IDF (IDF, 2015). Gemiddeld over de periode 2008-2014 wordt 87\% van de emissie (cradle-to-farm-gate) aan de productie van melk toegerekend en $13 \%$ aan de productie van vee en vlees.

Deze allocatie wordt ook toegepast bij de hoofdindicator 'broeikasgasemissie van de zuivelketen' van het subthema broeikasgasemissie. Omdat er naar de gehele zuivelketen wordt gekeken, zouden de broeikasgassen van de vee- en vleesproductie echter ook beter mee kunnen worden geteld. Dat is voor veel stakeholders in de sector intuïtiever en beter te begrijpen. Het wordt gezien als een inconsistentie met de andere subthema's, waar de impact van de sector niet aan verschillende producten wordt toegerekend. Het wordt aanbevolen om de impact van de broeikasgassen van de hele levenscyclus van de zuivel ('cradle to factory gate') als totaal zonder allocatie te presenteren.

De volledige rekenwijze voor de broeikasgasemissies wordt hier kort beschreven. Deze worden vastgesteld voor iedere emissiebron, per schakel van de Nederlandse zuivelketen (Figuur 3.1), en deze worden bij elkaar opgeteld. Voor een uitgebreidere beschrijving van de berekening wordt verwezen naar de sectorrapportage.

1. De hoeveelheden ingekochte, geproduceerde en de verkochte energie wordt vastgesteld voor iedere energiesoort, fossiel en niet-fossiel, en de energieconsumptie wordt berekend met deze gegevens. De bijdrage van melkveebedrijven wordt gebaseerd op de broeikasgasemissie van individuele bedrijven uit de steekproef van het Informatienet.

2. De broeikasgasemissie ten gevolge van energie wordt voor iedere ketenschakel berekend, door de consumptie van iedere energiesoort te vermenigvuldigen met zijn emissiefactor, en de emissiebijdragen van de verschillende soorten per keten bij elkaar op te tellen.

3. De broeikasgasemissies ten gevolge van energie wordt opgeteld bij de buiten het protocol bepaalde emissies voor iedere ketenstap. Dit betreft onder andere emissies uit mest en pens- en darmfermentatie op de melkveebedrijven en emissies ten gevolge van verpakkingsmateriaal bij de melkverwerkers.

4. De broeikasgasemissie van de melkveebedrijven wordt verdeeld over melk en vlees (ongeveer $87 \%$ voor melk en $13 \%$ voor vlees, volgens IDF (2015)).

5. De broeikasgasemissies van de Informatienetbedrijven worden met een verschillende wegingsfactor voor ieder bedrijf geaggregeerd naar een totaalemissie van de ketenschakel melkveehouderij. De broeikasgasemissies van verschillende ketenschakels worden gesommeerd, om tot de hoofdindicator 'broeikasgasemissie van de zuivelketen' te komen.

6. De ondersteunende indicator 'broeikasgasemissie per kg melk' wordt berekend door de aan melk toegerekende broeikasgasemissie van de melkveebedrijven te delen door de hoeveelheid afgeleverde melk. 


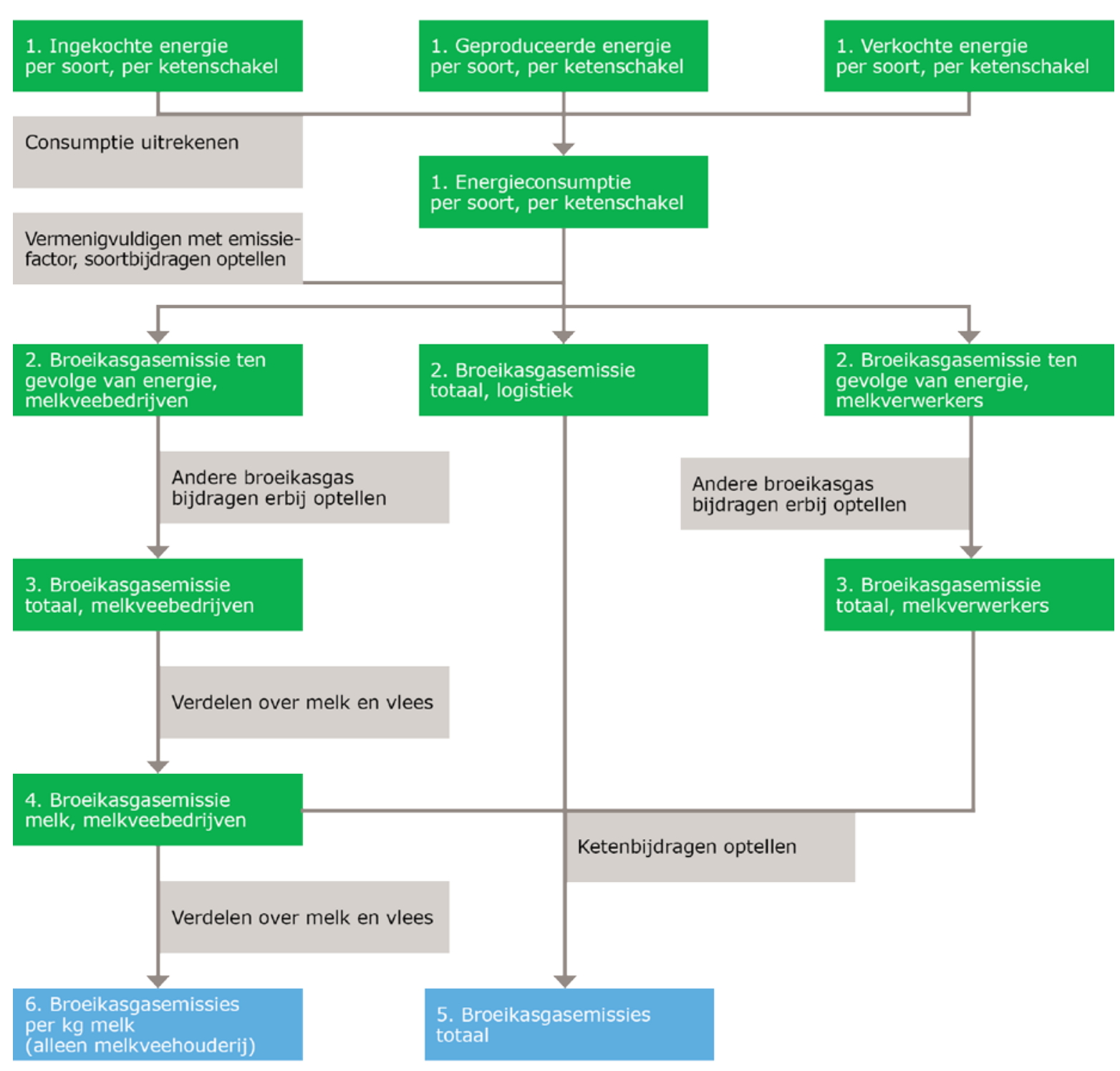

Figuur B6.1 Berekeningsmethode voor broeikasgasemissie indicator

\section{B6.2 Afbakening rond mest}

Broeikasgasemissies vinden plaats bij opslag, aanwending, transport en verwerking van mest. Niet al deze emissies zijn het gevolg van energiegebruik, maar de afbakening van de broeikasgasindicator wordt hier wel voor alle emissies rond mest behandeld. Voor een eenduidige behandeling waarbij dubbeltellingen worden voorkomen, wordt de 'cut-off/recycled content' benadering van Ecol nvent (2015b) gebruikt.

1. Eerst worden alle outputs van een productiestap geclassificeerd in: 'hoofdproduct', 'gewoon bijproduct', 'recyclebare materialen' en 'afval producten'. Mest wordt geclassificeerd als recyclebaar materiaal omdat het voldoet aan de voorwaarden dat het geen of weinig economische waarde heeft maar wel kan dienen als input voor een recycling activiteit.

2. Vervolgens wordt voor de mest bepaald waar de cut-off (het knippunt) ligt: welke emissies worden nog meegeteld voor het melkveebedrijf en welke worden toegerekend aan een volgende productiestap. Het knippunt ligt voor een recyclebaar materiaal aan het einde van de activiteit die het recyclebare materiaal produceert.

3. De consequenties van deze vaststelling worden uitgewerkt in Tabel B6.1. Mest toegepast op akkerbouwbedrijven krijgt niet de emissies toegerekend van de melkveehouderij, maar wel van de stappen tussen melkveehouderij en akkerbouwer. Zo zullen de emissies van het transport van mest worden toegerekend aan de ontvanger, evenals de emissie van de mestverwerking. Van de 
energie die wordt opgewekt bij mestvergisting wordt bepaald wat de milieu-impact is op basis van deze regels. De gebruiker van deze energie krijgt die milieu-impact toegekend.

\section{Tabel B6.1}

Toerekening van mest gerelateerde emissies aan melkveebedrijf

\begin{tabular}{|c|c|c|}
\hline Categorie & Bron & $\begin{array}{l}\text { Toerekenen aan } \\
\text { melkveebedrijf }\end{array}$ \\
\hline \multirow[t]{3}{*}{ Opslag } & Aangevoerde mest, emissie op het producerende bedrijf & Nee \\
\hline & Eigen mest, emissie op het eigen bedrijf & $\mathrm{Ja}$ \\
\hline & Afgevoerde mest, emissie op het eigen bedrijf & $\mathrm{Ja}$ \\
\hline \multirow[t]{2}{*}{ Aanwending } & Aangevoerde mest & $\mathrm{Ja}$ \\
\hline & Eigen mest & $\mathrm{Ja}$ \\
\hline \multirow[t]{2}{*}{ Transport } & Aanvoer van mest & $\mathrm{Ja}$ \\
\hline & Afvoer van mest & Nee \\
\hline
\end{tabular}

* Grootschalige mestverwerking op een melkveebedrijf wordt gezien als aparte bedrijfstak, die niet aan de melkveebedrijven wordt toegerekend. 
LEI Wageningen UR Postbus 29703

2502 LS Den Haag

T 0703358330

E publicatie.lei@wur.n!

www. wageningenUR. nl/lei

\section{Rapport}

LEI 2016-043

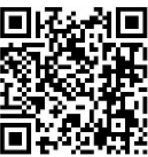

LEI Wageningen UR is een onafhankelijk, internationaal toonaangevend, sociaaleconomisch onderzoeksinstituut. De unieke data, modellen en kennis van het LEI bieden opdrachtgevers op vernieuwende wijze inzichten en integrale adviezen bij beleid en besluitvorming, en dragen uiteindelijk bij aan een duurzamere wereld. Het LEI maakt deel uit van Wageningen UR (University $\&$ Research centre). Daarbinnen vormt het samen met het Departement Maatschappijwetenschappen van Wageningen University en het Wageningen UR Centre for Development Innovation de Social Sciences Group.

De missie van Wageningen UR (University \& Research centre) is 'To explore the potential of nature to improve the quality of life'. Binnen Wageningen UR bundelen 9 gespecialiseerde onderzoeksinstituten van stichting DLO en Wageningen University hun krachten om bij te dragen aan de oplossing van belangrijke vragen in het domein van gezonde voeding en leefomgeving. Met ongeveer 30 vestigingen, 6.500 medewerkers en 10.000 studenten behoort Wageningen UR wereldwijd tot de aansprekende kennisinstellingen binnen haar domein. De integrale benadering van de vraagstukken en de samenwerking tussen verschillende disciplines vormen het hart van de unieke Wageningen aanpak. 


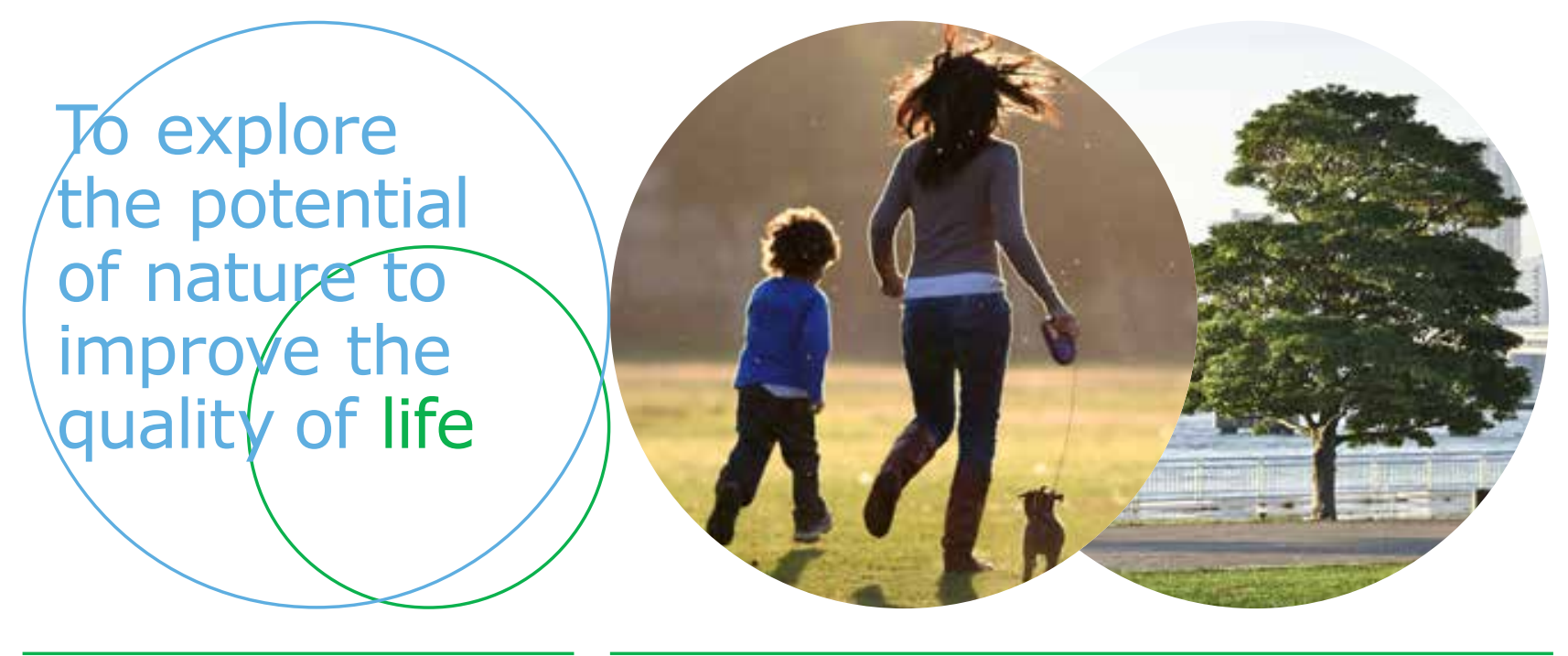

LEI Wageningen UR

Postbus 29703

2502 LS Den Haag

E publicatie.lei@wur.nl

www.wageningenUR.nl/lei

RAPPORT

LEI 2016-043

ISBN 978-94-6257-816-6
LEI Wageningen UR is een onafhankelijk, internationaal toonaangevend, sociaaleconomisch onderzoeksinstituut. De unieke data, modellen en kennis van het LEI bieden opdrachtgevers op vernieuwende wijze inzichten en integrale adviezen bij beleid en besluitvorming, en dragen uiteindelijk bij aan een duurzamere wereld. Het LEI maakt deel uit van Wageningen UR (University \& Research centre). Daarbinnen vormt het samen met het Departement Maatschappijwetenschappen van Wageningen University en het Wageningen UR Centre for Development Innovation van de Social Sciences Group.

De missie van Wageningen UR (University \& Research centre) is 'To explore the potential of nature to improve the quality of life'. Binnen Wageningen UR bundelen 9 gespecialiseerde onderzoeksinstituten van stichting DLO en Wageningen University hun krachten om bij te dragen aan de oplossing van belangrijke vragen in het domein van gezonde voeding en leefomgeving. Met ongeveer 30 vestigingen, 6.500 medewerkers en 10.000 studenten behoort Wageningen UR wereldwijd tot de aansprekende kennisinstellingen binnen haar domein. De integrale benadering van de vraagstukken en de samenwerking tussen verschillende disciplines vormen het hart van de unieke Wageningen aanpak. 